\title{
Insolvency or Liquidity Squeeze? Explaining Very Short-Term Corporate Yield Spreads
}

\author{
Dan Covitz and Chris Downing ${ }^{1}$
}

October 2, 2002

\footnotetext{
${ }^{1}$ This paper benefited from discussions with Mark Carey, Paul Harrison, Eric Heitfeld, and Calvin Schnure. Shannon Hart provided excellent research assistance; all errors and omissions remain the responsibility of the authors. This paper represents the views of the authors and does not necessarily represent the views of the Federal Reserve System or members of its staff. Please address correspondence to (Covitz): Federal Reserve Board, Mail Stop 89, Washington, DC 20551. Phone: (202) 452-5267. Fax: (202) 728-5887. E-Mail: dcovitz@frb.gov. (Downing): Federal Reserve Board, Mail Stop 89, Washington, DC 20551. Phone: (202) 452-2378. Fax: (202) 728-5887. E-Mail: cdowning@frb.gov.
} 


\begin{abstract}
In the first section of this paper, we document new stylized facts about very short-term (less than one year) and long-term investment-grade corporate yield spreads. We find that short-term yield spreads are sizable, averaging from 10 basis points on overnight commercial paper issued by firms with AAA long-term debt ratings, to 34 basis points on overnight paper issued by firms with BBB ratings. We also show that, at times, the correlations between many firms' short-term and long-term yield spreads are negative, typically during periods characterized by credit market disruptions. We then argue that the structural models of risky debt that have appeared in the literature cannot be reconciled with either of these stylized facts.

In the second section of this paper, we develop a structural model that generates levels and correlations of short-term and long-term risk spreads that are more consistent with what we observe. Our model departs from the literature by allowing for the possibility of payment delays when a firm's liquid asset position deteriorates. In essence, we weaken the assumption of perfect firm liquidity that is standard in insolvency-based models of defaultable debt. Intuitively, liquidity risk can generate sizable short-term debt spreads because the realized returns on short-term investments are relatively more sensitive to small increases in the length of the holding period. The presence of liquidity risk can also explain negative correlations between short-term and long-term spreads because liquidity risk need not be perfectly correlated with insolvency risk.

In the third section of the paper, using firm-level pricing and balance sheet information, we provide empirical evidence that, controlling for insolvency risk, liquid asset positions are important for the pricing of short-term debt, particularly during periods of credit market disruptions, but almost never matter for the pricing of long-term debt. The results are robust to different insolvency risk and liquidity risk measures. These results have implications for the pricing and hedging of short-term debt.
\end{abstract}




\section{Introduction}

The seminal paper by Merton (1974) provides a basic structural framework for valuing defaultable corporate debt. One of the principal strengths of the Merton approach is that it makes clear causal links between the price of a firm's debt and observables, thus providing specific testable predictions. However, the empirical evidence for the model and various of its extensions is somewhat mixed. Most empirical studies of early Merton-style models (Merton (1974), Black and Cox (1976), Geske (1977)) find that the models seriously under-predict the level of long-term corporate bond yield spreads (for example, Jones, Mason and Rosenfeld (1984) and Ogden (1987)). ${ }^{1}$ More recent empirical studies, including Lyden and Saraniti (2000) and Eom, Helwege and zhi Huang (2002), find that extensions of the Merton model (Leland and Toft (1996), Collin-Dufresne and Goldstein (2001)) produce higher long-term yield spreads, but underpredict spreads for large, well capitalized firms, and overpredict spreads for risky firms.

It is also well known that the Merton-style structural models have difficulty generating substantial short-term spreads because the underlying asset process is assumed to be continuous. This limitation is not inconsequential. Valuing risky debt with short maturities (under one year) is important for pricing the more than $\$ 1$ trillion of commercial paper issued by corporations in the U.S. each year. It is also important for secondary market transactions that involve bonds with little time remaining to maturity. ${ }^{2}$ However, surprisingly little attention has been paid in the literature to improving the performance of structural debt pricing models at the very short end of the maturity spectrum.

This paper makes a step toward filling this void. Our first contribution is to document some new stylized facts about short-term risk spreads and the relationships between shortand long-term risk spreads for investment-grade firms. Consistent with conventional wisdom,

\footnotetext{
1 "Yield spreads" are defined here and in the literature as the difference between the yield-to-maturity on the defaultable bond less the yield-to-maturity on a comparable maturity default-free bond. By "long-term", we mean bonds with more than one year to maturity.

${ }^{2}$ Warga (1991) suggests that these bonds may not trade frequently.
} 
we show that investment-grade short-term yield spreads are sizable. For example, we find that yield spreads range from 10 basis points on overnight commercial paper issued by firms with AAA long-term ratings, to 34 basis points on overnight paper issued by firms with $\mathrm{BBB}$ ratings. We also show that, at times, the correlations between many firms' short- and long-term yield spreads are negative, typically during periods characterized by disruptions to short-term credit markets.

These stylized facts suggest that a firm-level factor other than insolvency risk is driving short-term yield spreads. It seems implausible that the probability of insolvency over a four day horizon is so large as to explain the levels of short-term yield spreads that we observe, particularly given that the firms in our sample are all investment-grade. Put another way, if the likelihood of insolvency over a four day horizon were high enough to generate the observed spreads, then long-term yield spreads would have to be much higher than are observed. A similar argument can be made for why interest-rate risk is not sufficient to explain the level of short-term spreads. Of course, nonzero short-term spreads could also reflect jumps in the asset process, though we argue later that this is not the most plausible explanation. Regardless, insolvency-based models, with or without jumps in the asset process, cannot generate disparate moves in short- and long- term yield spreads. As a firm moves closer to (or away from) insolvency, all yield spreads rise (or fall). A model that includes a separate firm-level factor that, under certain circumstances, generates high short-term yield spreads could, however, be reconciled with these stylized facts.

The approach that the major rating agencies take to evaluating the creditworthiness of short-term and long-term debt issues is also suggestive of a separate factor most relevant to short-term debt holders. Indeed, the very fact that they maintain separate sets of ratings for each class of debt is itself suggestive of the presence of factors of specific concern to shortterm and long-term creditors. With regard to short-term debt, rating agencies stress the importance of the probability of timely repayment in addition to the likelihood of repayment. Key components of short-term ratings criteria include firm liquidity, access to alternative 
sources of short-term credit, and other liquidity-based factors. ${ }^{3}$

Our second contribution is the development of a multi-factor model that is consistent with the stylized facts that we uncover. Our approach is to extend Merton's basic structural model by dividing total firm assets into a fixed component and a liquid component, creating a model with two observable firm-level state variables. We posit the existence of a bound on liquid assets, below which a firm may experience difficulties in meeting its short-term obligations - it may encounter a so-called "liquidity squeeze". These assumptions reflect the realistic notion that firms require some level of liquid assets in order to operate smoothly to pay suppliers and salaries, and service debt on time, for example.

We argue that when a firm's liquid assets fall in value to low levels (for example, when earnings fall precipitously), the firm may be forced to liquidate fixed assets or obtain additional outside financing in order to meet its short-term obligations. These alternatives introduce the possibility that short-term creditors will not be repaid in a timely fashion. For example, in the case of asset liquidations, potential buyers must be located, the buyers must perform due diligence in order to ascertain the value of the assets, a deal must be negotiated, and so on - tasks that require days, if not weeks, to complete. Issuing long term securities will also likely lead to payment delays. Equity and bond sales involve road shows to locate potential investors, document filings, time for settlement, and the like, all of which take at least a few days to complete.

Of course, liquidity might also be provided by credit lines at banks or other short-term credit markets. However, with respect to credit lines, banks typically require 24 hours notice before such lines may be drawn. In addition, banks have the option to revoke the lines of solvent firms when they believe a material adverse change clause (standard in most loan agreements) may have been breached. Similarly, the ability to raise short-term debt is not guaranteed and may be subject to "sunspot" equilibria, analogous to those that generate bank runs in Diamond and Dybvig (1983). In other words, there may be multiple equilibria

\footnotetext{
${ }^{3}$ More recently, Moody's has announced that it will begin issuing "liquidity risk assessments" - a product designed directly for commercial paper investors.
} 
for firms with limited liquidity, one of which is that investors rationally choose not to purchase short-term debt, justified by the belief that other investors will not purchase the debt in later periods. The ability of a firm to roll over debt may also be hampered by market level events that disrupt liquidity more generally, such as the Russian Default Crisis in August 1998. Rather than model these effects explicitly, we simply assume the existence of a liquid asset boundary, and posit that when this boundary is violated investors will anticipate that firms might not be able to roll over their debt.

The notion that short-term creditors are concerned with the liquid asset positions of issuing firms is supported by the fact that commercial paper programs must be backed by bank lines of credit. ${ }^{4}$ The bank lines are designed to bridge temporary gaps between the liquid assets a firm has on hand and current expenditures. The presence of material adverse change clauses implies that these lines are not credit enhancements, further suggesting that they are mechanisms, albeit imperfect ones, for mitigating payment delays.

The possibility of payment delays is also supported by recent experience in the commercial paper market. In the past few years, the incidence of defaults in the form of payment delays in the commercial paper market far outweighs the incidence of defaults that lead to loss of principal. In fact, we are not aware of any loss of principal on very short term commercial paper. On the other hand, delays in principal repayment occur, albeit infrequently. For example, Edison International, the California power utility, stopped payments on its shortterm obligations in order to preserve cash in the face of skyrocketing electricity costs. After a delay of about a year, short-term creditors were repaid with accrued interest. Finally, of the defaults on commercial paper that have occurred in the last several years, none have involved overnight paper..$^{5}$

Our theoretical analysis abstracts from features in other extensions to Merton's model,

\footnotetext{
${ }^{4}$ In order to be eligible for purchase by money-market mutual funds, SEC regulation 2(a)-7 requires that commercial paper programs have the highest short-term rating from two major rating agencies. The rating agencies require liquidity support in the form of committed lines of credit at money-center banks in order to obtain their highest ratings.

${ }^{5}$ In fact, we are unaware of any defaults on overnight commercial paper.
} 
such as the incorporation of early default covenants as in Black and Cox (1976) and stochastic interest rates as in Longstaff and Schwartz (1995), among others. This allows us to focus on the implications of imperfect firm liquidity for debt prices. The prospect of payment delays intuitively affects short-term debt spreads more than long-term spreads. For example, a one day delay in the payment of principal and accrued interest on an overnight discount bond is a doubling of its maturity, while a one day delay in the payments on a 30 year bond only extends the maturity by a negligible fraction. The high sensitivity of short term bond prices to even remote possibilities of short payment delays allows the model to easily generate substantial short-term spreads. In addition, with two firm-level state variables the model can generate opposing moves in short- and long-term risk spreads.

Our theoretical framework also generates testable predictions. In particular, the model implies that liquidity risk - the risk that a firm will have to turn to fixed asset liquidations or to outside sources of funds to repay creditors - should be important for explaining the cross-sectional variation in short-term yield spreads, after controlling for insolvency risk, but it should have little explanatory power for the cross-sectional variation in long-term spreads.

Our third contribution is to test these predictions using firm-level panel data from 1998 to 2001. Specifically, we estimate cross sectional regressions of commercial paper spreads and bond spreads, and panel regressions of the difference between bond spreads and commercial paper spreads. We find that liquidity-risk is an important determinant for commercial paper spreads, but has little influence on bond spreads. Moreover, we also find that the importance of liquidity-risk for pricing short-term debt varies throughout our sample period. For instance, in our cross-sectional analyses, we find that liquidity risk was relatively important for pricing commercial paper issues in the fall of 1998. One explanation for this result is that following the collapse of Long Term Capital Management and the Russian default crisis in the fall of 1998, credit market disruptions may have forced firms to rely heavily on internal funds to meet short-term obligations. That is, the ability of some firms to avoid liquidity squeezes by rolling over short-term debt may have been limited. It is also 
possible that the market may have perceived weakness in the banking industry and thus questioned the stability of the liquidity support provided to firms by their credit lines. The cross-sectional regression results also indicate that liquidity risk was relatively important for pricing short-term commercial paper in the first quarter of 2001. This period was also characterized by disruptions in short-term credit markets, as the economy faltered and earnings of many firms plummeted. These interpretations of the cross-sectional results are buttressed by results from our panel regressions, which show that liquidity-risk influenced short-term debt pricing when average spreads in the commercial paper market were relatively high.

This paper is organized as follows. In the next section, we briefly review the related literature. In section 3, we develop stylized facts about short-term and long-term yield spreads. In section 4, we present our theoretical model, using it to explore the implications of payment delays for yield spreads and the co-movements of short- and long-term yield spreads. Section 5 presents the empirical evidence for our model, and section 6 concludes.

\section{Literature Review}

A growing literature is devoted to empirical testing of structural models of defaultable debt. Jones et al. (1984) is one of the first papers to systematically test the implications of a structural default model. While they find that the Merton (1974) model tends to underpredict credit spreads, their analysis relies upon callable long-term bonds and bond prices that are not necessarily derived from market transactions. ${ }^{6}$ Ogden (1987) also finds that the Merton model underpredicts spreads, using a sample of prices on newly-issued callable long-term bonds. The results of these early studies are difficult to interpret, because they rely on callable bonds. The observed spreads thus contain a component attributable to the call options. However, Lyden and Saraniti (2000) use a sample of non-callable long-term bonds issued by financial and non-financial firms, and find that the Merton (1974) and Longstaff

\footnotetext{
${ }^{6}$ Specifically, they rely on bond prices that may be matrix prices, which are widely believed to be inferior to dealer-quotes and market prices (Warga (1991), Warga and Welch (1993)).
} 
and Schwartz (1995) models underpredict spreads.

Eom et al. (2002) makes the most comprehensive test to date of structural models of defaultable debt. The authors test the Merton (1974), Geske (1977), Longstaff and Schwartz (1995), Leland and Toft (1996), and Collin-Dufresne and Goldstein (2001) models, using a sample of non-callable long-term bonds issued by nonfinancial firms with simple capital structures. ${ }^{7}$ In general, they find that all of the models underpredict spreads for "safe" firms - well capitalized firms rated as high-investment grade by the major rating agencies. The more recent Leland and Toft (1996) and Collin-Dufresne and Goldstein (2001) outperform the earlier models, but overpredict spreads for risky firms and underpredict spreads for safe firms.

Sarig and Warga (1989) uses a sample of discount bonds to demonstrate that yield spreads vary with maturity in a manner that is roughly consistent with Merton's model. Similarly, Helwege and Turner (1999) and He, Hu and Lang (2000) test the shape of the term credit structure implied by various of the structural models. All of the papers focus on long-term bonds, and find that, generally speaking, the shape of the long-term credit structure is roughly in line with what the Merton (1974) model predicts.

Our paper differs from all of the papers in the existing literature in that we are the first to consider the very short end of the term structure of risky debt. The purpose of our paper is not to make an explicit test of the implications of a particular model. Rather, we first generate some new stylized facts about the relationship between very short-term and long-term bond yields. We then propose a modification of the basic Merton (1974) model that can explain the stylized facts that we uncover, and present some empirical results that support our modeling approach. We leave direct testing of the model for future research.

\footnotetext{
${ }^{7}$ Financial firms are excluded so that the firms in the sample have comparable leverage ratios; the authors also exclude regulated utilities.
} 


\section{Stylized Facts about Short-Term Yield Spreads}

In order to study the pricing of risky debt at the very short end of the maturity spectrum, we construct a data set consisting of risk spreads for commercial paper issued by domestic U.S. corporations in the nonfinancial sector. The raw data are all commercial paper issues by firms in this sector for the period between January 1998 and December 2001. The data were obtained from the Depository Trust Company (DTC), the agent that clears and settles nearly all directly- and dealer-placed commercial paper. ${ }^{8}$ Except for a handful of extendable notes that explicitly penalize firms for payment delays, the issues in the sample are all discount bonds with no coupons or embedded options. Spreads are calculated as the annualized continuously compounded money market yield less the comparable maturity repurchase rate. ${ }^{9}$ The total number of issues in the sample is $1,965,674$.

Our first stylized fact is that yield spreads are sizable for commercial paper issued by programs with investment-grade long-term bond ratings. To show this, we divide the commercial paper issuers into four groups based on their long term bond ratings at the time the CP was issued. The ratings are Merrill Lynch's composite rating and are available on Bloomberg. ${ }^{10}$ There were 47,319 CP issues where the issuing firm carried a AAA long-term rating, 398,208 issues with AA ratings, 923,073 issues with A ratings, and 597,074 programs with BBB ratings. We further partition the data into 7 maturity categories: 1-4 days; 5-10 days; 11-24 days; 25-44 days; 45-74 days; 75-104 days, and 105-270 days. The maturity categories correspond to the categories reported in the Federal Reserve's H15 commercial paper release. Based on the information from the H15 release, issuance in the commercial paper market is concentrated at the shortest maturities. The quantity of commercial paper

\footnotetext{
${ }^{8} \mathrm{~A}$ tiny fraction of market participants still use physical clearance and settlement, but these account for less than five percent of market activity, according to DTC. For detailed information on the CP market and its clearance and settlement systems, see Stigum (1986) and Stigum (1990).

${ }^{9}$ Longstaff (2000) argues that general collateral repurchase rates are superior to Treasury bill yields as a proxy for short-term risk-free rates. In short, repos are overcollateralized with Treasury securities, are pure financial contracts not subject to the supply and demand factors affecting Treasury securities, and the repo market is very actively traded on a daily basis across a wide range of maturities.

${ }^{10}$ Merrill Lynch constructs the composite rating as an average of available ratings from the major rating agencies.
} 
in each maturity category (from shortest to longest maturity), expressed as a percentage of the total, is $59 \%, 9 \%, 10 \%, 12 \%, 6 \%, 3 \%$, and $1 \%$, respectively. The number of issues in each category, expressed as a percentage of the total number of issues, is $66 \%, 8 \%, 9 \%, 10 \%$, $4 \%, 2 \%$, and $1 \%$.

Figure 1 plots the par-value weighted average spread by maturity for issues by firms with the indicated long-term bond rating. ${ }^{11}$ The figure shows that the average yield spread for the shortest maturity CP (1-4 days) ranges from around 10 basis points for AAA issuers to 34 basis points for BBB issuers. The average spread for each rating class increases almost monotonically with maturity. At the longest maturity (75-270 days), the spread is approximately 22 basis points for AAA issuers, and 72 basis points for BBB issuers.

Figure 1: Short-Term Corporate Yield Spreads

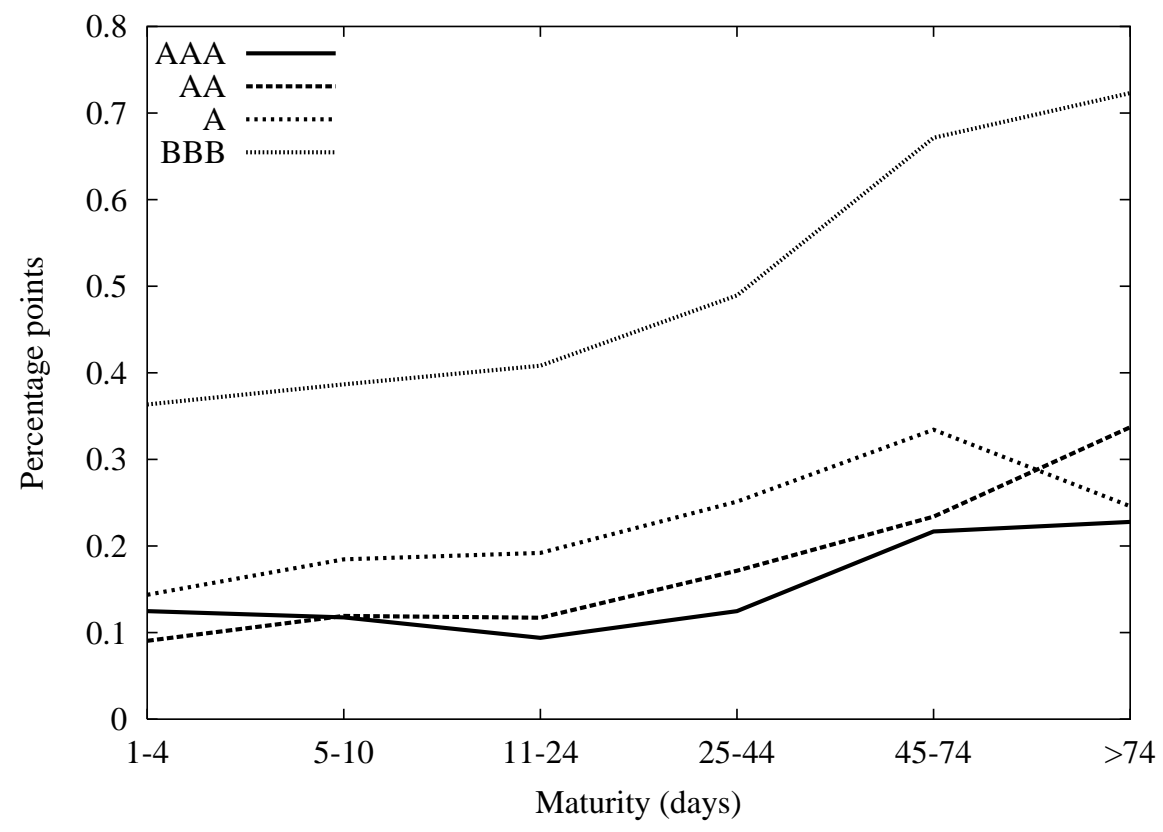

Our second stylized fact is that the correlations between long-term and short-term bond spreads are not always positive. Indeed, at times they are significantly negative. To demonstrate this fact, we calculate correlations at the firm-level by merging the commercial paper database with Merrill Lynch's bond database. The Merrill Lynch database contains

\footnotetext{
${ }^{11}$ When calculating average spreads across bonds, we always weight by par value rather than market value since we are constructing a measure of an expected spread.
} 
daily quotes and effective yields for a wide universe of corporate bonds. ${ }^{12}$ To construct our firm-level correlations, we calculate yield spreads relative to comparable maturity Treasury securities for each BBB-rated bond in the database, and then create an average long term yield spread for each issuer by computing the par-value weighted average spread across each firm's bonds with maturities ranging from 7 to 10 years. ${ }^{13}$ We restrict the sample in each quarter to those issuers that have at least 30 daily observations on short- and long-term yield spreads.

Figure 2 plots the lower quartile, median, and upper quartile of firm-level correlations between short and long-term risk spreads. As can be seen from the figure, the firm-level correlations tend to be positive, but at times are negative for a majority of firms. For example, in the third and fourth quarters of 1999, the correlations between short and longterm spreads were negative for the majority of firms, as investors were concerned about the possibility that the century date change would trigger widespread computer failures that could potentially disrupt short-term credit markets. The correlations were also negative for a sizable share of firms in the first quarter of 2001, a period notable for the large commercial paper and bond defaults by Pacific Gas and Electric and Southern California Edison in early January followed by three Federal Reserve rate cuts. The rate cuts appeared to improve investor confidence in long-term economic prospects, as long-term spreads narrowed over the quarter. ${ }^{14}$

Existing models for pricing risky debt have difficulty explaining either of the above stylized facts. To demonstrate this fact, we simulate spreads for discount bonds with maturities

\footnotetext{
${ }^{12}$ According to Merrill Lynch documentation available on Bloomberg, "Effective yield is the yield of a hypothetical bullet bond created by stripping out the option value of a bond with embedded optionality such as a call, put or sinking fund feature."

${ }^{13}$ We restrict the maturity range on the bonds so as to eliminate any possible interaction effects between the maturity of a firm's long-term debt and the insolvency and liquidity risk measures that we construct below.

${ }^{14}$ We have repeated these calculations using aggregate measures of risk spreads (Merrill Lynch corporate bond yield indices and composite commercial paper indices from the Federal Reserve's H15 release). Computing long-term spreads to both Treasuries and AAA-corporate yields, and short-term spreads to repo rates, we find largely the same results. This suggests that the correlations are not being driven by the specialness of Treasury securities owing to concerns about the future supply of Treasury bonds as a result of fiscal surpluses.
} 
Figure 2: Quarterly Correlations Between Daily Firm-Level Long- and Short-Term Spreads: Lower Quartile, Median, Upper Quartile

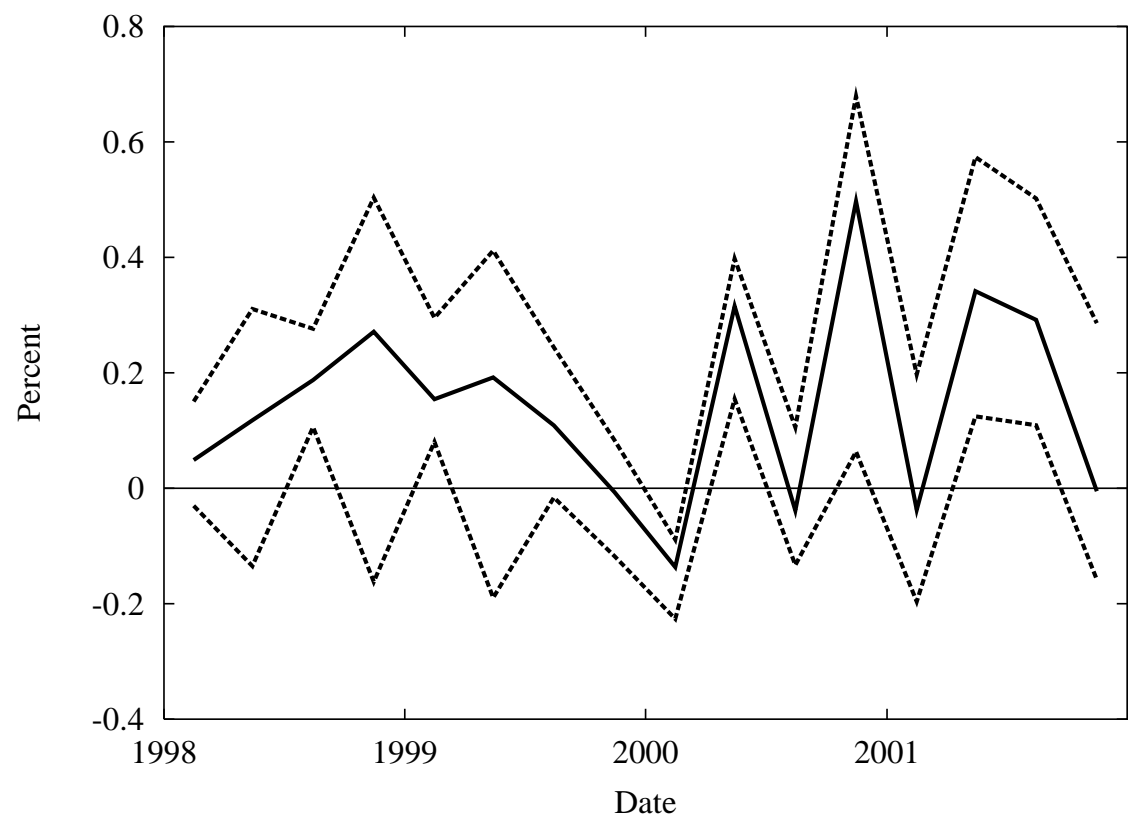

ranging from 1 day to 20 years with the closed form solutions in Merton (1974), Black and Cox (1976), Longstaff and Schwartz (1995). The parameter assumptions are chosen to correspond roughly to a $\mathrm{BBB}$ firm at an average point in the business cycle. We assume a debt-to-firm-value ratio of $1 / 3$, that the volatility of firm value is $25 \%$ per annum, and that the risk-free rate is $7 \% .{ }^{15}$

The predicted spreads for the three models are shown in figure 3. As expected, the lowest spreads at any maturity are generated by Black and Cox, since their model differs from Merton in that it allows early default covenants, which clearly increases the value of debt. The second highest spreads at any maturity are obtained from Merton, and the highest spreads are generated by Longstaff and Schwartz with the addition of stochastic interest rates. All three models predict essentially zero spreads on commercial paper with maturities less than 1 month. Moreover, only Longstaff and Schwartz generates more than

\footnotetext{
${ }^{15}$ The Longstaff and Schwartz (1995) model requires additional parameters to define the interest rate process and fractional recovery rate. We have used the parameters from their paper. The long-term mean of the short rate plus the market price of risk is $6 \%$, the degree of mean reversion is 1 , and the volatility of the short rate is $4 \%$. The writedown in default is $90 \%$.
} 
a negligible spread for maturities less than 1 year. Of course, these simulations are only conducted for one set of parameters. However, the inability of these models to generate spreads at very short maturities is robust to "reasonable" changes in the parameters. For example, lowering the risk free rate by 50 basis points, which generates higher spreads in the Longstaff and Schwartz model as the risk-neutral drift on the asset process falls with the interest rate, has essentially no impact on short-term yield spreads.

Figure 3: Simulated Risk-Spreads

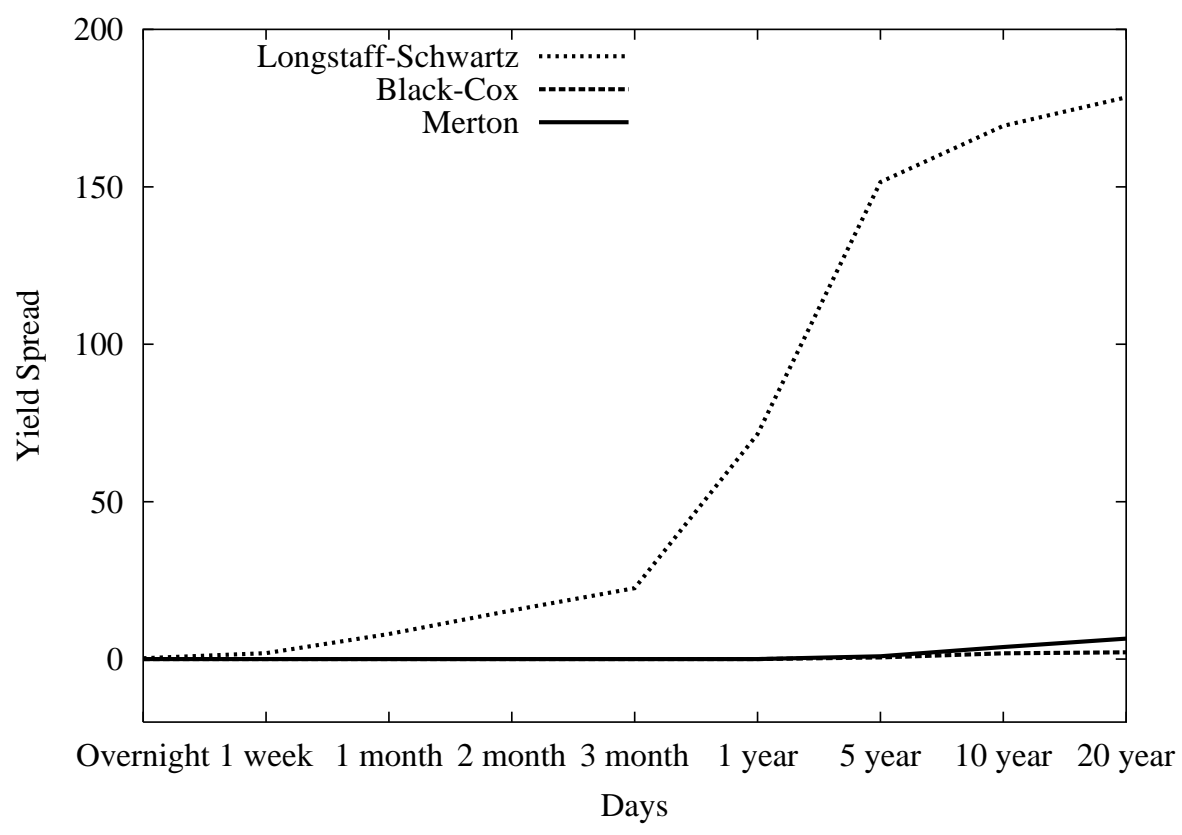

As mentioned at the outset, it is well known that the Merton-style structural models cannot generate significant short-term spreads because the asset process is continuous. One could allow discontinuous jumps in the asset process in an attempt to generate more sizable short-term spreads, but the economics behind a jump process sufficient to create insolvency over short horizons may be difficult to justify, particularly for the highly rated firms used to construct figure $1 .{ }^{16}$ Even the filing of a lawsuit of sufficient size that it could bankrupt the firm cannot trigger an immediate default, since such proceedings typically take years to

\footnotetext{
${ }^{16}$ We have conducted some simulation studies of the jump model appearing in Merton (1976). It is less clear how to parameterize this model, but under what seem to be plausible settings of the jump parameters, short-term spreads are virtually the same as under the original Merton model.
} 
wind their way through the court system, and the outcomes are very difficult to gauge ex ante.

Finally, these models, including those with jump modifications, are unable to generate negative correlations between long and short-term bonds. Adding a stochastic volatility component to the models will not generate negative short- and long-term yield spread correlations (nor will it generate sizable spreads), unless one makes counter-factual assumptions about the dynamic properties of asset volatilities (for recent research on volatility dynamics, see Andersen, Bollerslev, Diebold and Ebens (2001), Andersen, Bollerslev, Diebold and Labys (2002)). In the next section, we propose an alternative way of thinking about shortterm yield spreads that leads to a model capable of explaining the stylized facts we have just highlighted.

\section{Theory}

The value of any firm can be thought of as composed of two pieces. One piece consists of the fixed assets of the firm, loosely defined as assets that can be liquidated only after a relatively long period of time. The other piece of a firm's value consists of the liquid assets of the firm including, for example, cash, easily marketable financial instruments such as Treasury securities, and to a lesser degree trade receivables and inventories. This distinction between the assets of a firm is recognized by generally accepted accounting principals (GAAP). The label typically applied to liquid assets is current assets.

More formally, let $A_{t}$ denote the fixed assets of a firm, and let $L_{t}$ denote its liquid assets. Suppose that the values of these assets evolve over time according to geometric Brownian motions as follows:

$$
\begin{aligned}
& d A_{t}=\alpha_{A} A_{t} d t+\sigma_{A} A_{t} d W_{A, t}, \text { and } \\
& d L_{t}=\alpha_{L} L_{t} d t+\sigma_{L} L_{t} d W_{L, t} .
\end{aligned}
$$


The parameter $\alpha_{A}$ is the instantaneous expected rate of return on the firm's fixed assets per unit time, and $\sigma_{A}$ is the instantaneous variance of the value of its fixed assets per unit time. The parameters $\alpha_{L}$ and $\sigma_{L}$ have similar interpretations. The instantaneous expected rate of return on the firm's liquid assets per unit time is given by $\alpha_{L}$, and the volatility of its liquid assets per unit time is given by $\sigma_{L}$. The Wiener processes $W_{A, t}$ and $W_{L, t}$ are assumed to be correlated such that $E\left[d W_{A, t} d W_{L, t}\right]=\rho d t$.

The value of the unlevered firm is the sum of its fixed and liquid assets, given by:

$$
V_{t}=A_{t}+L_{t}
$$

A very simple application of Itô's Lemma delivers the dynamics for total firm value:

$$
d V_{t}=\left(\alpha_{A} A_{t}+\alpha_{L} L_{t}\right) d t+\sigma_{A} A_{t} d W_{A, t}+\sigma_{L} L_{t} d W_{L, t}
$$

It can be seen from this formulation that we have simply started from the basic model of Merton (1974) and split firm value into two pieces that evolve according to separate but correlated processes.

To examine the implications of imperfect liquidity on the term structure in a tractable setting, we follow Merton (1974) and assume that the firm has outstanding two classes of claims: a single, homogeneous class of debt, and equity with a residual claim on firm value. The assumption of a single class of debt is made for convenience and is easily weakened (see Geske (1977)).

With respect to the debt contract, we assume that: (1) the firm promises to pay a total of $B$ dollars at date $T$; (2) if $L_{T} \leq C$, where $C$ is a "liquidity boundary" to be defined below, then there is some probability $p$ that debt-holders will have to wait an additional length of time $d$ for repayment; (3) the firm cannot issue new debt, cannot pay a dividend, and cannot repurchase shares prior to repayment of debt. Assumption (3) eliminates from consideration any additional cash flows beyond the debt payment, further simplifying the problem. It is 
straightforward to weaken this assumption.

In assumption (2), we weaken the assumption of perfect firm liquidity, and introduce the possibility of delays in debt repayment. In the context of our model, the liquidity boundary $C$ can be viewed as equal to the level of outstanding debt $B$. In other words, we enforce the requirement that a firm must have sufficient liquid assets on hand in order to pay off its creditors. However, in reality, it is likely that $C$ will involve many more factors, such as tax payments, sizable payments to vendors, and other obligations coming due over a relatively short horizon.

In reality, $p$ is likely to be quite small, and $d$ just a few days or weeks. Nevertheless, this is all that is required in order to explain the stylized facts about yield spreads that we highlighted in the previous section. The basic intuition is that small probabilities of short payment delays matter far more to very short-term debt holders than to long-term debt holders. Consider the most extreme case of a holder of overnight commercial paper. Even a one day delay in repayment cuts the realized return on his or her investment in half. Hence small probabilities of short delays can generate substantial yield spreads for very short-term debt instruments. Under our model, the short-term yield spreads discussed in the previous section are not the usual yield spreads arising as a result of the possibility of insolvency. Rather, they are related to the possibility of payment delays.

Implicit in this formulation is the assumption that such short delays do not lead debtholders to force bankruptcy proceedings. This seems reasonable, since bankruptcy typically involves delays of years, not just a few days, and bankruptcy proceedings also involve significant uncertainties regarding repayment. The situation we model here is one in which the creditors are sufficiently certain of repayment in a short time so as to forgo the bankruptcy option. This is not to say that payment delays are not defaults; they are defaults that do not trigger bankruptcy. Importantly, in this model we assume that delays are not strategic. That is, firms only delay if their liquid assets are insufficient to repay the debt. Assuming away strategic delay is reasonable, since firms that exhibit such behavior are likely to lose 
access to public credit markets.

Standard arguments for risk-neutral valuation show that the value of the debt issue, denoted by $F$, evolves according to:

$$
\begin{aligned}
& \frac{1}{2} \sigma_{A}^{2} A^{2} F_{A A}+\frac{1}{2} \sigma_{L}^{2} L^{2} F_{L L}+\rho \sigma_{A} \sigma_{L} A L F_{A L}+ \\
& \quad\left(\alpha_{A}-\lambda_{A} \sigma_{A}\right) A F_{A}+\left(\alpha_{L}-\lambda_{L} \sigma_{L}\right) L F_{L}-r F-F_{\tau}=0,
\end{aligned}
$$

where $\tau \equiv T-t$ is the time to maturity, $r$ is the risk-free rate, $F_{t}=-F_{\tau}$, and $\lambda_{A}$ and $\lambda_{L}$ are the prices of risk for the fixed and liquid assets, respectively. The parabolic partial differential equation in (5) is subject the following boundary conditions:

$$
\begin{aligned}
F(0,0, t) & =0 \\
F(A, L, T) & =\left\{\begin{array}{cl}
B & \text { if } L>C \text { and } V>B \\
p B e^{-r d}+(1-p) B & \text { if } L \leq C \text { and } V>B \\
V & \text { if } V \leq B
\end{array}\right.
\end{aligned}
$$

The boundary condition (6) arises from the fact that zero is an absorbing boundary for both the fixed and liquid asset processes; firm value is zero at this point, and thus the debt claim is worthless. The set of conditions (7) formalizes the payment delay mechanism. When the liquid assets of a firm reach the liquidity boundary $C$, with probability $p$ the debt-holder receives what is essentially a risk-free bond with face value $B$ and time $d$ to maturity, and with probability $1-p$ receives full payment of $B$ immediately.

Under this formulation, the total value of the firm remains independent of its capital structure. This is because the payment delay mechanism that we have introduced does not dissipate firm value, it simply results in a transfer from short-term creditors to equity holders. In essence, our delay mechanism is a forced rollover of debt at the risk-free rate; there are no bankruptcy costs or taxes in our model. As a result, under our assumptions of complete markets and no arbitrage, investors can perfectly replicate the payoffs of risky debt and levered equity, and in so doing force the values of levered and unlevered firms to 
be identical.

To make the intuition of our model more concrete, we consider a parameterization of the model shown in table 1 . We set $\alpha_{A}=\alpha_{L}=r$ and $\lambda_{A}=\lambda_{L}=0$ for simplicity. It is straightforward to relax these assumptions; here we want to focus on the role of payment delays in determining the term structure of credit spreads, so we abstract from issues of risk-adjustment. ${ }^{17}$ We have also set the fixed asset value to a level implying a very low risk of insolvency over short- to medium-term horizons, consistent with the fact that only investment-grade firms are able to obtain very short-term unsecured credit. The credit spreads implied by this parameterization are shown in table 2 .

As can be seen in the table, payment delays have virtually no impact on long-term debt. For debt maturities over one year, spreads rise by just a fraction of a basis point as the firm's level of liquid asset holdings deteriorates. For shorter-maturity debt, however, the effects are more dramatic. Thirty-day and seven-day credit spreads widen rapidly as liquidity falls and the possibility of payment delays rises. Notice also that when liquid assets are low (i.e., when liquidity-risk is high) it is possible that spreads are decreasing and then increasing in maturity. However, for lower levels of liquid assets, still capable of generating substantial short-term spreads, yield spreads are everywhere increasing in maturity. ${ }^{18}$

The results in table 2 suggest why short-term borrowers almost without exception either pledge collateral (bank loans), or maintain committed lines of credit with creditworthy banks (commercial paper). If bankruptcy were the only alternative for short-term lenders to recover their principal in the event of a default, short-term credit would be extremely expensive due to the long delays in the bankruptcy process, even for firms where the like-

\footnotetext{
${ }^{17}$ Our assumptions are consistent with a model in which it is possible to hold $A$ and $L$ directly in a portfolio (i.e., that they are tradable assets). This is the tack taken by Merton (1974) and others when forming replicating portfolios of positions in the firm, the firm's debt, and risk-free debt. As is well known, replication is a sufficient condition to price an asset under risk-neutrality; here we employ the necessary conditions that markets are complete and arbitrage opportunities have been eliminated by market forces.

${ }^{18}$ The model is capable of generating a variety of yield curve shapes. In addition to the U-shaped pattern shown here (which was actually observed in the corporate debt markets in January of 2000), monotonically increasing, hump-shaped, and other configurations are all possible, depending on the configuration of the parameters of the model.
} 
lihood of bankruptcy is remote. Recently, firms (at the urging of their underwriters) have also attempted to mitigate the impact of liquidity risk on short-term debt costs by writing a contract that allows firms the option of delaying repayment, typically at a penalty yield spread to the London Interbank Offer Rate (LIBOR). The put options embedded in these so-called "extendable commercial notes" (ECNs) have encountered resistance from investors, however, possibly due to institutional factors.

The model is also able to generate imperfectly correlated moves in the term credit structure of the sort observed in the data. When the firm receives a negative shock to its liquid assets, but a positive shock to its fixed assets, short-term credit spreads can rise at the same time that long-term spreads contract. An example of when this might be the case is in a recession when the firm's earnings are falling rapidly, but monetary and fiscal policy are being brought to bear in a way that improves the longer-term prospects for the firm.

The state space diagram shown in figure 4 illustrates how short-term and long-term credit spreads can move in opposite directions in our model. The horizontal axis gives the level of liquid assets $L$, while the vertical axis gives the level of fixed assets $A$. The amount of debt outstanding is $B$. When total firm value falls below the amount of debt outstanding, the firm is insolvent - the shaded triangular region. The liquidity boundary is shown by the vertical line at $C$ on the horizontal axis. The arrow depicts one possible trajectory through the state space where short-term and long-term credit spreads will move in opposite directions. On this trajectory, the distance to the default boundary is increasing, but the distance to the liquidity boundary is decreasing. Long-term credit spreads will fall, but short-term spreads will rise. In addition to the distances to the default and liquidity boundaries, the degree to which the different spreads move will depend on the maturity of the debt, the volatility of fixed and liquid assets, the probability of delay, and the expected length of delay. 
Figure 4: State Space Diagram

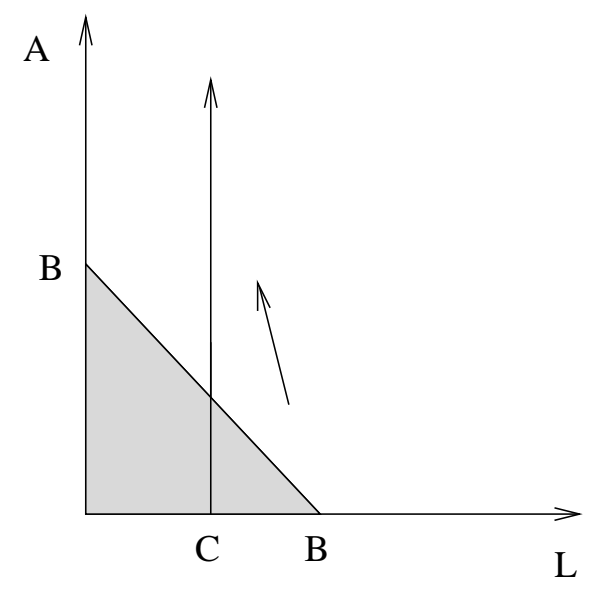

\section{$5 \quad$ Empirical Analysis}

\subsection{Methodology}

The analysis of the previous section indicates that some measure of the level of firms' liquid assets should help to explain the cross-sectional variation in short-term yield spreads, but that the measure should have little explanatory power for the cross-sectional variation in long-term spreads. In addition, the evolution of liquid assets through time should help to explain the time-series dynamics of short- and long-term credit spreads, as we discussed in sections 3 and 4 . In this section, we test these predictions using quarterly firm-level data.

Our strategy is to test whether proxies for liquidity risk help explain the cross-sectional variation in short-term yield spreads but not in long-term yield spreads, after controlling for insolvency risk. We use a three-pronged approach: First, we estimate cross-sectional regressions of commercial paper spreads; second, we estimate cross-sectional regressions of bond spreads; and third, we estimate panel regressions of the difference between bond spreads and commercial paper spreads. All spread, solvency, and liquidity variables are expressed in logs whenever possible; hence the coefficients may be interpreted as elasticities.

We consider a number of proxies for insolvency risk. Our preferred measure is the log of the one-year ahead expected default frequency (log EDF) constructed by KMV Corporation 
for each firm. In essence, the EDF is an implementation of the one-factor Merton (1974) model of defaultable debt that serves as the point of departure for our two-factor model. KMV uses equity prices and balance sheet information to estimate a firm's asset value and asset variance. These estimates, along with the level of firm liabilities, are then used to estimate an EDF. ${ }^{19}$

We consider three other controls for the risk of insolvency, all constructed so that higher values indicate lower insolvency risk. A natural, though nä̈ve, measure is the log of the ratio of total assets to total liabilities (i.e., the inverse of leverage). On the face of it, we expect this control to perform poorly relative to the EDF, because it does not explicitly account for the variance of asset values. We also consider the log of the interest coverage ratio (log of net income divided by interest expenses). This ratio is not a clean measure of insolvency risk, since net income and interest expense are also linked to a firm's liquidity risk. Our last measure of insolvency risk is long term rating. Like the coverage ratio, ratings are not a pure measure of insolvency risk. The possibility that these insolvency measures also reflect liquidity leads to conservative tests of whether the liquidity risk measures are important for the pricing of short-term debt.

Turning to measures of liquidity-risk, an ideal measure would be the sum of the value of liquid assets plus the value of liquidity facilities, less short-term liabilities due within 30days (the maturity of commercial paper used in our empirical analysis), normalized by the volatility of liquid assets. One proxy for the sum of liquid assets and liquidity facilities is current assets. ${ }^{20}$ Current assets contains assets that are highly liquid, such as cash, as well as assets that are likely to facilitate short-term credit arrangements at banks, such as accounts receivable. One measure of a firm's short-term liabilities is the firm's current liabilities.

\footnotetext{
${ }^{19}$ For more information on how KMV constructs EDFs, see http://www.kmv.com/insight/index.html.

${ }^{20}$ Income statement and balance sheet data from Compustat are quarterly. Current assets includes cash, short-term investments, inventories, accounts receivable, deposits, deferred taxes, advances, prepayments, and deferred charges. Our measures of liquid assets likely do not directly measure access to liquidity facilities. Measures such as firm size and credit rating are likely to be positively correlated with a firm's access to external sources of liquidity.
} 
This measure is rough, since it includes liabilities up to 1 year, far beyond the maturity of the commercial paper that is used in our empirical analysis. ${ }^{21}$ A reasonable proxy for the variance of liquid assets is the variance of total assets calculated by KMV using each firm's equity price volatility and other information.

With these points in mind, we consider three proxies for liquidity-risk. All of the proxies are constructed so that higher values correspond to lower liquidity-risk. Our first proxy is the log of current assets relative to current liabilities, $\log (\mathrm{CA} / \mathrm{CL})$, the $\log$ of what is commonly referred to as the "current ratio." This measure does not attempt to account for the variance in liquid assets. The second proxy attempts to control for the variance of liquid assets, and is obtained by taking the difference between current assets and current liabilities and dividing by KMV's measure of asset volatility, $(\mathrm{CA}-\mathrm{CL}) / \sigma_{A}{ }^{22}$ We do not take the $\log$ of this measure because the numerator is negative for a substantial number of firms. Our final proxy for liquidity risk is the log of current assets relative to total assets, $\log (\mathrm{CA} / \mathrm{TA})$. The normalization of current assets by total assets has two justifications. First, firms with relatively more assets are likely to be relatively large firms, and larger firms are more likely to have more volatile (in absolute terms) liquid assets. Second, firms with more assets are likely to have higher liquid asset boundaries, since they tend to have greater (again in absolute terms) debt service requirements, payrolls, and short-term debt obligations. ${ }^{23}$

As was the case in section 3, the quarterly short-term and long-term spreads are for investment-grade, non-financial firms. Commercial paper spreads are calculated relative to comparable maturity repurchase rates, and bond spreads are taken relative to comparable off-the-run Treasuries, as discussed in section 3. To control for the impact of maturity on spreads, we restrict commercial paper issues to be those with maturity less than 35 days, and

\footnotetext{
${ }^{21}$ Current liabilities includes all accounts payable, income taxes, and all debt due within one year, including bank acceptances, brokerage companies drafts payable, current portion of long-term debt, loan installments, loans payable to parents, subsidiaries, stockholders or officers of the company, notes payable, and sinking fund payments.

${ }^{22}$ To be consistent with the numerator, $\sigma_{A}$ is the absolute, not the percentage, volatility.

${ }^{23}$ The question of the optimal mix of short-term and long-term debt has not been addressed in the literature. An advanced treatment of the question of optimal leverage is the series of papers Leland (1994) and Leland and Toft (1996). In these papers, a firm can only choose a single maturity of long-term debt.
} 
restrict bond issues to those with maturities between 7 and 10 years. We also require that a firm have an EDF measure from KMV and balance sheet information from Compustat in order to be included in a quarterly sample. ${ }^{24}$

We first estimate separate cross-sectional regressions for each quarter from the first quarter of 1998 through the second quarter of 2001, for a total of 14 quarters. The motivation for separate quarterly regressions is that it allows us to easily examine how the coefficients vary over time. For quarter $t=1,2, \ldots, 14$, our regression specification for commercial paper spreads is given by

$$
\mathrm{CPS}_{t, i}=\beta_{0}+\beta_{1}(\text { Liquidity Risk })_{t, i}+\beta_{2}(\text { Solvency Risk })_{t, i}+\epsilon_{t, i}, \quad i=1,2, \ldots, N_{t}
$$

where $\mathrm{CPS}_{t, i}$ is the log of the commercial paper spread in quarter $t$ for firm $i$, "Liquidity Risk" and "Solvency Risk" refer to proxies for both types of risk, and $N_{t}$ is the number of firms in the regression for quarter $t$. The specification for bond spread regressions differ only in that we replace $\mathrm{CPS}_{t, i}$ with the log of the bond spread, denoted by $\mathrm{BONDS}_{t, i}$.

In addition, we estimate a panel regression where the dependent variable is the difference between $\mathrm{BONDS}_{t, i}$ and $\mathrm{CPS}_{t, i}$. The panel regressions contain somewhat fewer observations, because some firms issue CP but do not have long-term bonds, and vice-versa. The specification for the panel regressions is given by:

$$
\begin{aligned}
& \mathrm{BONDS}_{t, i}-\mathrm{CPS}_{t, i}=\beta_{0}+\beta_{1} F_{i}+\beta_{2} Q_{t}+ \\
& \beta_{3}(\text { Liquidity Risk })_{t, i}+\beta_{4}(\text { Solvency Risk })_{t, i}+ \\
& \beta_{5}(\text { BBB less 10-year T })_{t}+ \\
& \beta_{6}(\mathrm{CPDUM})_{t}+\beta_{7}(\text { Interaction term })_{t, i}+ \\
& \epsilon_{t, i} \text { for } i=1,2, \ldots, N_{t}
\end{aligned}
$$

where the variables $F_{i}$ and $Q_{t}$ denote firm-specific and quarterly dummy variables, respec-

\footnotetext{
${ }^{24}$ Univariate statistics for the variables used in our cross-sectional regressions are provided in appendix A.
} 
tively; for notational simplicity we have omitted the log notation (all of the variables except the firm-specific and quarterly dummies are in logs). In addition to the liquidity and solvency controls used in the individual spread regressions, we control for aggregate long-term risk-spreads using the log of the difference between Merrill Lynch's BBB yield index and the 10-year constant-maturity Treasury rate (BBB less 10-year T). We attempt to identify periods when short-term credit markets are stressed with the dummy variable CPDUM, defined to be one when the quarterly average of spreads between the composite A2/P2 rate and comparable maturity repo rates is greater than 50 basis points, and zero otherwise. In order to test our conjecture that firm-level liquidity matters more when short-term credit markets are stressed than at other times, we also include the interaction of CPDUM with the relevant liquidity risk measure (denoted by "Interaction term" in equation (9)). For reference, all of the variables that we use in our regressions are summarized in table 3.

\subsection{Results}

The detailed quarterly regression results are displayed in appendix A; table 4 summarizes our main results. In panel $\mathrm{A}$ of the table, we present results from 3 different specifications of our cross-sectional commercial paper spread $\left(\mathrm{CPS}_{t, i}\right)$ regressions. All three specifications contain the log of KMVs EDF to control for insolvency risk, but contain different controls for liquidity-risk. The first specification uses $\log (\mathrm{CA} / \mathrm{CL})$, the second uses $(\mathrm{CA}-\mathrm{CL}) / \sigma_{A}$, and the third uses $\log (\mathrm{CA} / \mathrm{TA})$. The table presents the number of cross-sections in which a coefficient is significantly different from zero at the 5 percent confidence level, and also presents the mean coefficient estimates.

The results displayed in panel A indicate that both insolvency-risk and liquidity-risk significantly impact bond prices. The coefficients on the log of the EDF, shown in the first row, are significant in every cross-section, in all three specifications, and the mean coefficient estimates for each specification range from 0.26 to 0.28 . The interpretation of these results is that a 1 percent increase in a firm's default probability, on average, leads to about a 27 basis 
point increase in its commercial paper spread. The coefficients on log $(\mathrm{CA} / \mathrm{CL})$, presented in the second row, are significantly negative (at the 5 percent error level) in 12 out of the 14 short-term spread regressions. The mean coefficient estimate is -0.30 , which indicates that, on average, a 1 percent increase in $\mathrm{CA} / \mathrm{CL}$ leads to a 30 basis point decrease in an issuer's commercial paper spread. The results are similar for the second and third liquidity risk proxies, $(\mathrm{CA}-\mathrm{CL}) / \sigma_{A}$, and $\log (\mathrm{CA} / \mathrm{TA})$, presented in the third and fourth rows. ${ }^{25}$

The results in Panel B show that insolvency-risk helps explain bond spreads, but liquidityrisk does not. The specifications presented in Panel B are identical to the specifications in Panel A, except the dependent variable is now $\mathrm{BONDS}_{t, i}$ instead of $\mathrm{CPS}_{t, i}$. The coefficients on $\log (\mathrm{EDF})$, shown in the first row, are all significant and the mean coefficient estimates are similar to those in the commercial paper spread regressions. As shown in the second and third rows, none of the coefficients on $\log (\mathrm{CA} / \mathrm{CL})$ or $(\mathrm{CA}-\mathrm{CL}) / \sigma_{A}$ are significant. Moreover, only one of the coefficients for $\log (\mathrm{CA} / \mathrm{TA})$, shown in the fourth row, is significant. The mean coefficient estimates for all the liquidity variables are close to zero.

The panel regression results for the spread of spread regressions, shown in Panel C, confirm the importance of liquidity for short-term spreads relative to long-term spreads, and show that it varies over time. The specifications presented in Panel $\mathrm{C}$ are identical to the specifications in Panel A and B, except the dependent variable is now the difference between $\mathrm{BONDS}_{t, i}$ and $\mathrm{CPS}_{t, i}$. The coefficients on $\log (\mathrm{EDF})$, shown in the first row, are not significant, which is not surprising, since it appears in the cross-sectional regressions to affect bond and commercial paper spreads with roughly the same magnitude. The coefficients on the liquidity variables, shown in the second through fourth rows, are are also insignificant. In contrast, the coefficients on the interactions between the liquidity proxies and CPDUM (a dummy variable for above average composite risk-spreads in the quarter), shown in the seventh row, are all significant and positive, with values ranging from 0.15 and 0.24 . These results suggests that during times of stress in the commercial paper market, firm liquidity

\footnotetext{
${ }^{25}$ Using two-tailed tests, the results are nearly the same as we report here.
} 
becomes important for pricing short-term debt relative to pricing long-term debt. As shown in the fourth and fifth columns, the controls for aggregate changes in commercial paper and bond spreads, proxied by CPDUM and the difference between the BBB yield index and the 10-year treasury, are significant and have the expected signs.

The time-series patterns of the cross-sectional coefficient estimates (shown in the appendix) also suggest that the importance of liquidity risk increases during periods of market stress. For example, consider the coefficient estimates for $(\mathrm{CA}-\mathrm{CL}) / \sigma_{A}$ (table 9$)$. While the coefficients on this measure are often negative and significant in the CP spread regressions, their predictive power strengthens during periods characterized by market disruptions. For example, in the fall of 1998, credit markets were severely disrupted in the wake of the Russian debt default and the meltdown of Long-Term Capital Management. The coefficient estimates are highly significant in the third quarter of 1998 , reaching a value of -0.335 , well above the mean coefficient estimate. This suggests that the near-closure of debt markets during this episode forced firms to rely more heavily on internal funds to meet short-term obligations, raising the possibility of liquidity problems, and this was clearly reflected in short-term credit spreads. Similarly, at the end of 1999, when Y2K concerns were running high, and in the first half of 2001, as the economy slid into recession and the earnings of many firms plummeted, the coefficient estimates again reached very negative and significant values.

\subsection{Robustness}

To test the robustness of our results, we next consider the alternative insolvency measures discussed earlier. ${ }^{26}$ Table 5 displays the results from CP and bond spread regressions where

\footnotetext{
${ }^{26}$ We have carried out exhaustive additional robustness checks of all of our main results. Our conclusions are qualitatively the same if we (separately and under many combinations of the following): (i) do not take log transforms, (ii) normalize current assets by total liabilities instead of total assets, (iii) do not restrict the maturities of the long-term bonds, (iv) make standard heteroscedasticity corrections, (v) directly control for maturity, (vi) make small changes to the definition of the CPDUM definition, (vii) interpolate the COMPUSTAT data to allow monthly regressions, and under a variety of other changes to our basic specification.
} 
we include the $\log$ of EDF, the log of the ratio of total assets to total liabilities $(\log (\mathrm{TA} / \mathrm{TL}))$, the log of net income to interest expense (NIIE), and the log of long-term rating. The table is structured with the same three panel format as in table 4 .

The inclusion of these additional measures has some effect on the results, but the general conclusions are robust. Each liquidity measure enters significantly into 4 of 14 CP regressions, and none of the bond spread regressions. The values of the coefficients on the liquidity variables range from 0.11 to 0.17 . The coefficients on long-term rating are significant in all specifications, with the expected sign, and values ranging from -1.35 to -1.31 . The additional solvency measures perform poorly - they are seldom significant. In the panel regressions, the coefficients on the interaction terms between CDUM and the liquidity variables is still significant, and the coefficient values range from 0.28 to 0.20 , slightly larger than in the first specification. The only significant solvency-risk measure is $\log (\mathrm{TA} / \mathrm{TL})$, with coefficient values ranging from -0.73 to -0.92 .

In the forgoing analysis, we have not considered the importance of industry membership in the determination of spreads. There are a number of reasons why industry membership might be important to both $\mathrm{CP}$ and bond spreads, making industry membership a variable that is difficult to categorize as either a liquidity control or an insolvency control - it is a bit of both. Firms in different industries may have different "natural" liquidity boundaries due to the nature of the businesses of firms in the industry. To the extent that this is the case, industry membership will act as a proxy for the liquidity boundary and for liquidity risk. On the other hand, industries perform differently through the business cycle. For example, the telecom sector has underperformed the rest of the market over the time period we consider; it is likely that firms in this industry have moved closer to their insolvency boundaries as well as toward their liquidity boundaries (in fact, many telecom firms have defaulted and/or gone bankrupt over the period). Lastly, it is important to note that recovery rates vary widely across industries (see Altman and Kishore (1996)), and this is likely to play a role in determining the cross-sectional variation of bond spreads (though we expect it would play 
little role in determining CP spreads, where recoveries are almost always total).

In table 6, we present the results of cross-sectional and panel spread regressions that include industry dummies in addition to the variables reported in table 4 . The industry dummies are significant in just one of the CP spread regressions, and the average coefficient values are relatively small. Industry membership plays a slightly larger role in determining bond spreads, though the coefficients on the industry dummy variables are significant in only a handful of the regressions. The industry dummy variables are also mostly insignificant in the panel regressions. The coefficient estimates on the liquidity variables are significant in most of the cross-sectional regressions of commercial paper spread, but in almost none of the cross-sectional bond spread regressions. Therefore, the basic result on the role of liquidity is largely unchanged: liquidity appears to matter more for CP spreads than for bond spreads, particularly during periods of stress in the commercial paper market.

\section{Conclusion}

We have developed a model capable of explaining important stylized facts about the relationship between very short-term and long-term yield spreads, namely, that very short-term yield spreads are larger than can be plausibly explained by insolvency-based models, and that, at various times, short-term and long-term yield spreads are negatively correlated. Our explanation for these features of observed risk spreads rests on a distinction between the fixed and liquid assets of a firm. We proposed a simple model in which a firm with a low level of liquid assets may be forced to turn to outside sources of funds to meet its short-term obligations. Raising outside funds always entails some possibility of a delay in payments to creditors, and delays matter much more to very short-term creditors than to long-term creditors. Using simulations and realistic calibrations, we demonstrated that even small probabilities of short delays can explain the stylized facts outlined above. We then provided empirical evidence based on firm-level data in support of our model. Using a variety 
of insolvency-risk and liquidity-risk proxies, we found that measures of liquidity risk help explain short-term spreads, particularly during periods of market stress, but have little explanatory power for long-term spreads. The main results are robust to controls for industry type, as well as to different adjustments for bond maturities.

The model developed in this paper is based on readily observed data on a firm, and thus could serve as the basis for a practical tool for consistently pricing the short-term and longterm debt of a firm. Some obvious extensions to the model would further enhance its realism. For example, a stochastic interest rate could be considered, along the lines of Longstaff and Schwartz (1995). Furthermore, the model could serve as the basis for investigations into optimal debt structure, along the lines of Leland and Toft (1996), in which the firm chooses not only how much debt to hold, but also the proportions of short-term and long-term debt. In this application, the model could deliver prescriptions for debt structure that are tied to the volatilities of long-term and liquid asset holdings, as well as their correlations.

Our findings have implications for the estimation of reduced form models for pricing risky debt (for example, Duffie and Singleton (1999)). Firm-level liquidity is more important for pricing short-term debt than for pricing long-term debt, suggesting that reduced form models of yield spreads should include controls for aggregate firm liquidity. Models that omit this factor are likely to produce seriously misleading predictions for short-term risk spreads. 


\section{Table 1: Parameters for simulations}

The table displays the parameters used in the simulations in the paper. Unless otherwise stated, these values are held fixed in the different comparative statics calculations.

\begin{tabular}{lr}
\hline $\mathrm{r}$ & 0.07 \\
$\sigma_{A}$ & 0.25 \\
$\sigma_{L}$ & 0.50 \\
$\rho$ & 0.80 \\
$\mathrm{~B}$ & $\$ 1.00$ \\
$\mathrm{C}$ & $\$ 0.25$ \\
$\mathrm{p}$ & 0.01 \\
$\mathrm{~d}$ & $7 / 365$ \\
$\mathrm{~V}$ & $\$ 3.00$ \\
\hline
\end{tabular}

Table 2: Risk spreads for zero coupon bonds for different values of $L$

The table displays the risk spreads in basis points for zero coupon bonds of the indicated maturities when the level of liquid assets is as given in the first column. The other parameters of the model are as shown in table 1. Note that the amount of outstanding debt is normalized to $\$ 1 ; L$ and $C$ are also given in dollars.

\begin{tabular}{lrrrrr}
\hline & \multicolumn{5}{c}{ Years to Maturity } \\
\cline { 2 - 6 } $\mathrm{L}$ & 10 & 5 & 1 & 0.08 & 0.02 \\
\hline 0.25 & 16.9 & 6.4 & 1.2 & 15.1 & 64.8 \\
0.26 & 16.9 & 6.4 & 1.2 & 10.7 & 37.0 \\
0.27 & 16.8 & 6.4 & 1.2 & 8.6 & 16.3 \\
0.28 & 16.8 & 6.4 & 1.1 & 6.8 & 5.3 \\
0.29 & 16.8 & 6.3 & 1.1 & 5.2 & 2.1 \\
0.30 & 16.7 & 6.3 & 1.1 & 2.7 & 0.4 \\
\hline
\end{tabular}


Table 3: Regression Variable Definitions

\begin{tabular}{|c|c|}
\hline Mnemonic & Definition \\
\hline $\log (E D F)$ & $\begin{array}{l}\text { The log of the one year ahead expected default } \\
\text { frequency. }\end{array}$ \\
\hline $\log (\mathrm{TA} / \mathrm{TL})$ & $\begin{array}{l}\text { The log of the ratio of total assets to total } \\
\text { liabilities. }\end{array}$ \\
\hline $\log (\mathrm{NIIE})$ & The log of the inverse interest coverage ratio. \\
\hline $\log$ (Long-term rating) & $\begin{array}{l}\text { The log of long-term rating, where the long- } \\
\text { term ratings have been converted to a numeric } \\
\text { scale with higher numbers representing better } \\
\text { credit quality. }\end{array}$ \\
\hline $\log (\mathrm{CA} / \mathrm{CL})$ & $\begin{array}{l}\text { The log of the ratio of current assets to current } \\
\text { liabilities. }\end{array}$ \\
\hline$(\mathrm{CA}-\mathrm{CL}) / \sigma_{\mathrm{A}}$ & $\begin{array}{l}\text { The ratio of current assets minus current lia- } \\
\text { bilities to asset volatility. }\end{array}$ \\
\hline $\log (\mathrm{CA} / \mathrm{TA})$ & $\begin{array}{l}\text { The log of the ratio of current assets to total } \\
\text { assets. }\end{array}$ \\
\hline BBB less 10-year $\mathrm{T}$ & $\begin{array}{l}\text { The quarterly average spread of BBB corpo- } \\
\text { rate yields over } 10 \text {-year Treasury yields. }\end{array}$ \\
\hline 10-year T less 3-month $\mathrm{T}$ & $\begin{array}{l}\text { The quarterly average spread of } 10 \text {-year Trea- } \\
\text { sury yields over } 3 \text {-month treasury yields. }\end{array}$ \\
\hline CPDUM & $\begin{array}{l}\text { Dummy variable that is one when the quar- } \\
\text { terly average spread of } \mathrm{A} 2 / \mathrm{P} 2 \text { 30-day com- } \\
\text { mercial paper yields over } 30 \text {-day repurchase } \\
\text { rates exceeds } 50 \text { basis points, and zero other- } \\
\text { wise. }\end{array}$ \\
\hline Interaction term & $\begin{array}{l}\text { Interaction between CPDUM and the relevant } \\
\text { liquidity proxy. }\end{array}$ \\
\hline Transportation & Firms with SIC codes of 4000-4999. \\
\hline Retail/Wholesale Trade & Firms with SIC codes of 5000-5999. \\
\hline Services & Firms with SIC codes of 7000-9999. \\
\hline Other & Firms with SIC codes of 0-1999. \\
\hline Firm-specific dummy variables & 180 firm-specific dummy variables. \\
\hline Quarter dummy variables & 14 quarter dummy variables. \\
\hline
\end{tabular}




\section{Table 4: Liquidity Matters More for Commercial Paper Spreads than for Bond Spreads}

Panels A and B present summary statistics for cross-sectional regressions of nonfinancial commercial paper and bond spreads (in logs), respectively, on proxies for solvency and liquidity risk. The regressions are estimated for each quarter from 1998:Q1 through 2001:Q2. Panel C presents the results of a regression of the log of long-term spreads less the log of short-term spreads on proxies for solvency and liquidity risk, using a panel of firm-level data covering the same period. The panel regression includes a full set of quarter-dummies and firm-dummies, which are not reported in order to conserve space. A **' symbol indicates that the mean coefficient estimate is significant at a $5 \%$ level and carries the expected sign (a one-tailed test).

\begin{tabular}{|c|c|c|c|c|c|c|}
\hline \multirow{4}{*}{$\begin{array}{l}\text { Panel A } \\
\text { Log Commercial } \\
\text { Paper Spread }\end{array}$} & \multicolumn{2}{|c|}{ Model 1} & \multicolumn{2}{|c|}{ Model 2} & \multicolumn{2}{|c|}{ Model 3} \\
\hline & \multirow{3}{*}{$\begin{array}{c}\text { Mean } \\
\text { Coefficient } \\
\text { Estimate }\end{array}$} & \multirow{3}{*}{$\begin{array}{l}\text { Number } \\
\text { Significant }\end{array}$} & \multirow{3}{*}{$\begin{array}{c}\text { Mean } \\
\text { Coefficient } \\
\text { Estimate }\end{array}$} & \multirow{3}{*}{$\begin{array}{l}\text { Number } \\
\text { Significant }\end{array}$} & \multirow{3}{*}{$\begin{array}{c}\text { Mean } \\
\text { Coefficient } \\
\text { Estimate }\end{array}$} & \multirow{3}{*}{$\begin{array}{l}\text { Number } \\
\text { Significant }\end{array}$} \\
\hline & & & & & & \\
\hline & & & & & & \\
\hline $\log (\mathrm{EDF})$ & 0.26 & 14 & 0.27 & 14 & 0.28 & 14 \\
\hline $\log (\mathrm{CA} / \mathrm{CL})$ & -0.30 & 12 & & & & \\
\hline$(\mathrm{CA}-\mathrm{CL}) / \sigma_{\mathrm{A}}$ & & & -0.22 & 10 & & \\
\hline $\log (\mathrm{CA} / \mathrm{TA})$ & & & & & -0.28 & 14 \\
\hline $\mathrm{T}$ & \multicolumn{2}{|c|}{14} & \multicolumn{2}{|c|}{14} & \multirow{2}{*}{\multicolumn{2}{|c|}{14}} \\
\hline $\mathrm{N}$ & \multirow{2}{*}{\multicolumn{2}{|c|}{$\begin{array}{c}2,072 \\
21.8 \%\end{array}$}} & \multirow{2}{*}{\multicolumn{2}{|c|}{$\begin{array}{l}2,071 \\
21,4 \%\end{array}$}} & & \\
\hline Mean Adj.- $R^{2}$ & & & & & \multicolumn{2}{|c|}{$25.7 \%$} \\
\hline Panel B & \multicolumn{2}{|c|}{ Model 1} & \multicolumn{2}{|c|}{ Model 2} & \multicolumn{2}{|c|}{ Model 3} \\
\hline \multirow{3}{*}{$\begin{array}{l}\text { Log Bond } \\
\text { Spread }\end{array}$} & Mean & & Mean & & Mean & \\
\hline & Coefficient & Number & Coefficient & Number & Coefficient & Number \\
\hline & Estimate & Significant & Estimate & Significant & Estimate & Significant \\
\hline $\log (\mathrm{EDF})$ & 0.20 & 14 & 0.20 & 14 & 0.20 & 14 \\
\hline $\log (\mathrm{CA} / \mathrm{CL})$ & 0.07 & 0 & & & & \\
\hline$(\mathrm{CA}-\mathrm{CL}) / \sigma_{\mathrm{A}}$ & & & 0.04 & 0 & & \\
\hline $\log (\mathrm{CA} / \mathrm{TA})$ & & & & & -0.02 & 1 \\
\hline $\mathrm{T}$ & \multicolumn{2}{|c|}{14} & \multicolumn{2}{|c|}{14} & \multicolumn{2}{|c|}{14} \\
\hline $\mathrm{N}$ & \multirow{2}{*}{\multicolumn{2}{|c|}{$\begin{array}{c}2,326 \\
33.9 \%\end{array}$}} & & & & \\
\hline Mean Adj.- $R^{2}$ & & & \multicolumn{2}{|c|}{$\begin{array}{l}2,325 \\
33.8 \%\end{array}$} & \multicolumn{2}{|c|}{$33.3 \%$} \\
\hline Panel C & \multicolumn{2}{|c|}{ Model 1} & \multicolumn{2}{|c|}{ Model 2} & $\mathrm{Mo}$ & el 3 \\
\hline LOg Ratio or Dond spread to & & & & & & \\
\hline Commercial Paper Spread & $\begin{array}{c}\text { Coefficient } \\
\text { Estimate }\end{array}$ & $\begin{array}{l}\text { Standard } \\
\text { Error }\end{array}$ & $\begin{array}{l}\text { Coefficient } \\
\text { Estimate }\end{array}$ & $\begin{array}{l}\text { Standard } \\
\text { Error }\end{array}$ & $\begin{array}{c}\text { Coefficient } \\
\text { Estimate }\end{array}$ & $\begin{array}{l}\text { Standard } \\
\text { Error }\end{array}$ \\
\hline $\log (\mathrm{EDF})$ & 0.02 & 0.03 & 0.02 & 0.03 & 0.01 & 0.03 \\
\hline $\log (\mathrm{CA} / \mathrm{CL})$ & -0.11 & 0.11 & & & & \\
\hline$(\mathrm{CA}-\mathrm{CL}) / \sigma_{\mathrm{A}}$ & & & -0.08 & 0.09 & & \\
\hline $\log (\mathrm{CA} / \mathrm{TA})$ & & & & & 0.18 & 0.12 \\
\hline $\log$ BBB less 10-year T & $1.14^{*}$ & 0.42 & $1.15^{*}$ & 0.42 & $1.10^{*}$ & 0.42 \\
\hline CPDUM & $-0.55^{*}$ & 0.17 & $-0.55^{*}$ & 0.17 & -0.31 & 0.19 \\
\hline Interaction term & $0.24^{*}$ & 0.09 & $0.18^{*}$ & 0.08 & $0.15^{*}$ & 0.05 \\
\hline Firm-specific dummy variables & & & (not $\mathrm{re}$ & orted) & & \\
\hline Quarter dummy variables & & & (not re & orted) & & \\
\hline $\mathrm{N}$ & & & & & & \\
\hline Adj.- $R^{2}$ & & & & & 47 & \\
\hline
\end{tabular}




\section{Table 5: Robustness to Additional Insolvency Risk Controls}

Panels A and B present summary statistics for cross-sectional regressions of nonfinancial commercial paper and bond spreads (in logs), respectively, on the same proxies for liquidity risk used for the regressions in table 4, and some additional insolvency risk controls. The regressions are estimated for each quarter from 1998:Q1 through 2001:Q2. Panel C presents the results of a regression of the log of long-term spreads less the log of short-term spreads on proxies for solvency and liquidity risk, using a panel of firm-level data covering the same period. The panel regression includes a full set of quarter-dummies and firm-dummies, which are not reported in order to conserve space. A ${ }^{*}{ }^{\prime}$ symbol indicates that the mean coefficient estimate is significant at a $5 \%$ level and carries the expected sign (a one-tailed test).

\begin{tabular}{|c|c|c|c|c|c|c|}
\hline \multirow{3}{*}{$\begin{array}{l}\text { Panel A } \\
\text { Log Commercial } \\
\text { Paper Spread }\end{array}$} & \multicolumn{2}{|c|}{ Model 1} & \multicolumn{2}{|c|}{ Model 2} & \multicolumn{2}{|c|}{ Model 3} \\
\hline & Mean & & Mean & & Mean & \\
\hline & $\begin{array}{l}\text { Coefficient } \\
\text { Estimate }\end{array}$ & $\begin{array}{c}\text { Number } \\
\text { Significant }\end{array}$ & $\begin{array}{l}\text { Coefficient } \\
\text { Estimate }\end{array}$ & $\begin{array}{l}\text { Number } \\
\text { Significant }\end{array}$ & $\begin{array}{l}\text { Coefficient } \\
\text { Estimate }\end{array}$ & $\begin{array}{c}\text { Number } \\
\text { Significant }\end{array}$ \\
\hline $\log (\mathrm{EDF})$ & 0.09 & 6 & 0.09 & 6 & 0.10 & 6 \\
\hline $\log (\mathrm{TA} / \mathrm{TL})$ & 0.25 & 0 & 0.23 & 0 & 0.10 & 0 \\
\hline $\log (\mathrm{NIIE})$ & -0.06 & 5 & -0.07 & 5 & -0.05 & 3 \\
\hline log (Long-term rating) & -1.35 & 14 & -1.35 & 14 & -1.31 & 14 \\
\hline $\log (\mathrm{CA} / \mathrm{CL})$ & -0.17 & 4 & & & & \\
\hline$(\mathrm{CA}-\mathrm{CL}) / \sigma_{\mathrm{A}}$ & & & -0.13 & 4 & & \\
\hline $\log (\mathrm{CA} / \mathrm{TA})$ & & & & & -0.11 & 4 \\
\hline $\mathrm{T}$ & \multicolumn{2}{|c|}{14} & \multicolumn{2}{|c|}{14} & \multirow{2}{*}{\multicolumn{2}{|c|}{14}} \\
\hline $\mathrm{N}$ & \multirow{2}{*}{\multicolumn{2}{|c|}{$\begin{array}{l}1,795 \\
42.4 \%\end{array}$}} & & & & \\
\hline Mean $\mathrm{Adj} .-R^{2}$ & & & \multicolumn{2}{|c|}{$42.2 \%$} & \multicolumn{2}{|c|}{$42.3 \%$} \\
\hline Panel B & \multicolumn{2}{|c|}{ Model 1} & \multicolumn{2}{|c|}{ Model 2} & \multicolumn{2}{|c|}{ Model 3} \\
\hline \multirow{3}{*}{$\begin{array}{l}\text { Log Bond } \\
\text { Spread }\end{array}$} & Mean & & Mean & & Mean & \\
\hline & Coefficient & Number & Coefficient & Number & Coefficient & Number \\
\hline & Estimate & Significant & Estimate & Significant & Estimate & Significant \\
\hline $\log (\mathrm{EDF})$ & 0.10 & 14 & 0.10 & 14 & 0.10 & 12 \\
\hline $\log (\mathrm{TA} / \mathrm{TL})$ & 0.08 & 0 & 0.10 & 0 & 0.15 & 0 \\
\hline $\log (\mathrm{NIIE})$ & 0.01 & 1 & 0.01 & 1 & 0.00 & 2 \\
\hline log (Long-term rating) & -0.85 & 14 & -0.86 & 14 & -0.88 & 14 \\
\hline $\log (\mathrm{CA} / \mathrm{CL})$ & 0.06 & 0 & & & & \\
\hline$(\mathrm{CA}-\mathrm{CL}) / \sigma_{\mathrm{A}}$ & & & 0.06 & 0 & & \\
\hline $\log (\mathrm{CA} / \mathrm{TA})$ & & & & & 0.04 & 0 \\
\hline $\mathrm{T}$ & & & & & & \\
\hline $\mathrm{N}$ & \multirow{2}{*}{\multicolumn{2}{|c|}{$\begin{array}{l}1,945 \\
56.1 \%\end{array}$}} & \multirow{2}{*}{\multicolumn{2}{|c|}{$\begin{array}{l}1,945 \\
56.1 \%\end{array}$}} & \multirow{2}{*}{\multicolumn{2}{|c|}{$\begin{array}{l}1,945 \\
56.1 \%\end{array}$}} \\
\hline Mean Adj.- $R^{2}$ & & & & & & \\
\hline Panel C & \multicolumn{2}{|c|}{ Model 1} & \multicolumn{2}{|c|}{ Model 2} & \multicolumn{2}{|c|}{ Model 3} \\
\hline \multirow[t]{2}{*}{ Commercial Paper Spread } & Coefficient & Standard & Coefficient & Standard & Coefficient & Standard \\
\hline & Estimate & Error & Estimate & Error & Estimate & Error \\
\hline $\log (\mathrm{EDF})$ & 0.02 & 0.04 & 0.02 & 0.04 & 0.01 & 0.04 \\
\hline $\log (\mathrm{TA} / \mathrm{TL})$ & $-0.92^{*}$ & 0.33 & $-0.90^{*}$ & 0.32 & $-0.73^{*}$ & 0.32 \\
\hline $\log ($ NIIE) & 0.04 & 0.04 & 0.04 & 0.04 & 0.02 & 0.04 \\
\hline $\log$ (Long-term rating) & -0.12 & 0.30 & -0.11 & 0.30 & -0.08 & 0.30 \\
\hline $\log (\mathrm{CA} / \mathrm{CL})$ & -0.01 & 0.13 & & & & \\
\hline$(\mathrm{CA}-\mathrm{CL}) / \sigma_{\mathrm{A}}$ & & & -0.01 & 0.11 & & \\
\hline $\log (\mathrm{CA} / \mathrm{TA})$ & & & & & 0.23 & 0.13 \\
\hline $\log$ BBB less 10-year T & $1.26^{*}$ & 0.48 & $1.28^{*}$ & 0.48 & $1.20^{*}$ & 0.47 \\
\hline CPDUM & $-0.61^{*}$ & 0.19 & $-0.61^{*}$ & 0.20 & -0.31 & 0.21 \\
\hline Interaction term & $0.28^{*}$ & 0.10 & $0.21^{*}$ & 0.09 & $0.20^{*}$ & 0.06 \\
\hline Firm-specific dummy variables & & & (not $r e$ & orted) & & \\
\hline Quarter dummy variables & & & (not re & orted) & & \\
\hline $\mathrm{N}$ & & & & & & \\
\hline Adj.- $R^{2}$ & & & & & & \\
\hline
\end{tabular}


Table 6: Liquidity Matters More for Within-Industry Commercial Paper Spreads than for Within-Industry Bonds Spreads

Panels A and B present summary statistics for cross-sectional regressions of nonfinancial commercial paper and bond spreads (in logs), respectively, on the same proxies for liquidity risk used for the regressions in table 4, and industry-specific dummy variables (the omitted industry category is "Manufacturing"). The regressions are estimated for each quarter from 1998:Q1 through 2001:Q2. Panel C presents the results of a regression of the log of long-term spreads less the log of short-term spreads on proxies for solvency and liquidity risk, using a panel of firm-level data covering the same period. The panel regression includes a full set of quarter-dummies, which are not reported in order to conserve space. The firm-level dummies are not used in this panel regression, because each industry-specific dummy is perfectly collinear with the firm-specific dummies for the firms in that industry. A ${ }^{\prime *}$ ' symbol indicates that the mean coefficient estimate is significant at a $5 \%$ level and carries the expected sign (a one-tailed test).

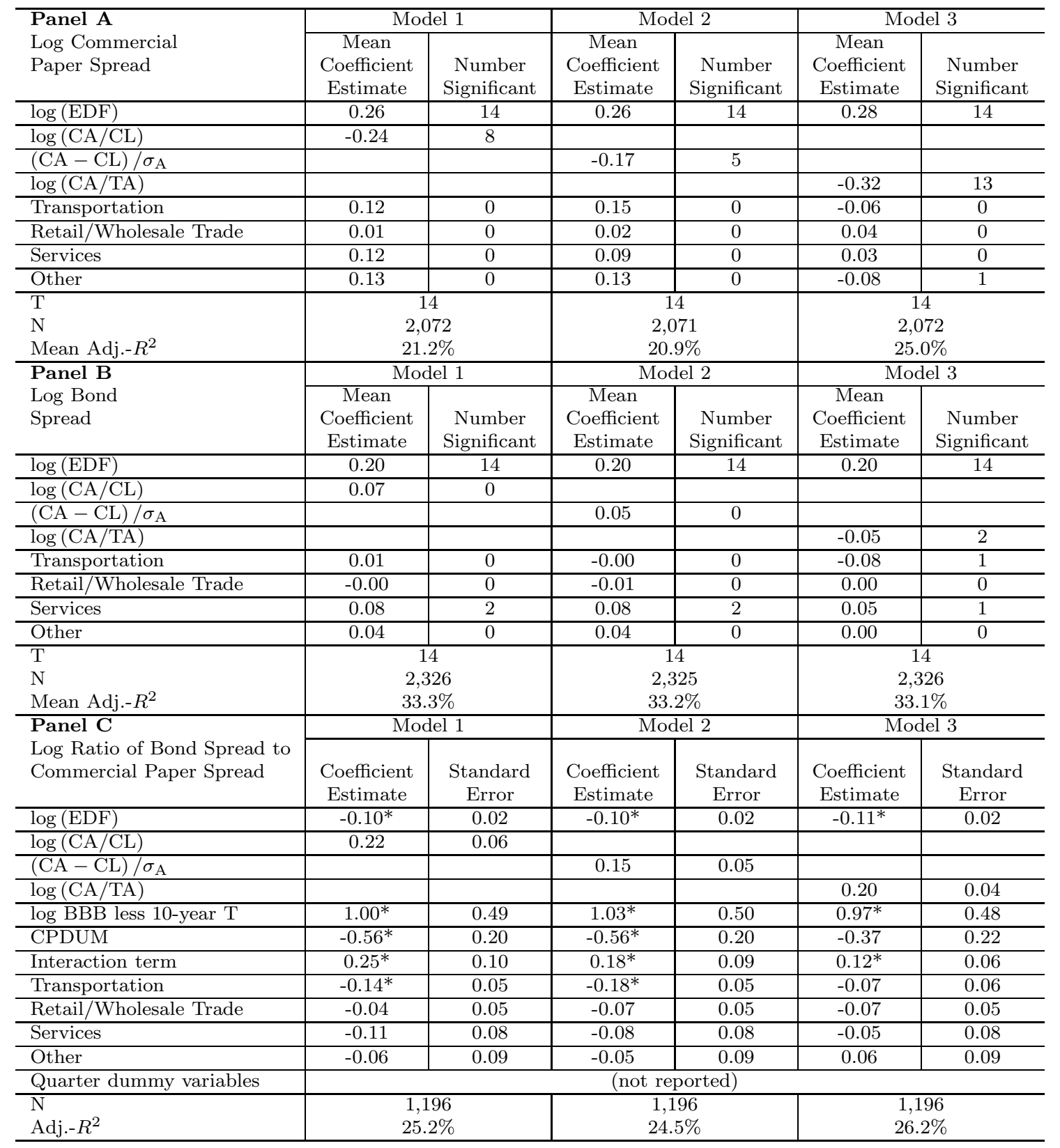




\section{A Regression Results}

This appendix provides detailed information on the variables and regression results reported in table 4. Table 7 below displays the means of the variables we use in the regressions by quarter. Tables 8-10 display the quarterly regression results. Tables 11-14 provide similar information for the bond regressions. We have omitted the details of the other regressions to conserve space; the information is available upon request.

Table 7: Means of variables for commercial paper spread regressions

\begin{tabular}{cccccccc}
\hline & \multicolumn{7}{c}{ Average } \\
Year & Quarter & $\mathrm{N}$ & Log Spread & $\log (\mathrm{EDF})$ & $\log \left(\frac{\mathrm{CA}}{\mathrm{CL}}\right)$ & $\frac{\mathrm{CA}-\mathrm{CL}}{\sigma_{A}}$ & $\log \left(\frac{\mathrm{CA}}{\mathrm{TA}}\right)$ \\
\hline 1998 & 1 & 114 & -2.04353 & -3.06292 & 0.10715 & 0.09885 & -1.37929 \\
1998 & 2 & 123 & -1.89836 & -2.85604 & 0.13408 & 0.12480 & -1.33226 \\
1998 & 3 & 132 & -1.66407 & -2.35855 & 0.11733 & 0.17878 & -1.28508 \\
1998 & 4 & 141 & -1.41916 & -2.25874 & 0.12454 & 0.12542 & -1.31219 \\
\hline 1999 & 1 & 135 & -1.92382 & -1.96966 & 0.12180 & 0.10743 & -1.32878 \\
1999 & 2 & 158 & -1.60890 & -2.12777 & 0.08995 & 0.07035 & -1.38748 \\
1999 & 3 & 137 & -1.73795 & -1.75341 & 0.09613 & 0.09761 & -1.32633 \\
1999 & 4 & 131 & -1.54247 & -1.48434 & 0.06253 & 0.06196 & -1.33905 \\
\hline 2000 & 1 & 161 & -2.11311 & -1.19137 & 0.04701 & 0.02853 & -1.37919 \\
2000 & 2 & 172 & -1.33524 & -0.96282 & 0.05293 & 0.02415 & -1.36136 \\
2000 & 3 & 180 & -1.81915 & -0.91392 & 0.04768 & 0.03379 & -1.33216 \\
2000 & 4 & 177 & -1.34646 & -1.09090 & 0.04671 & 0.02404 & -1.30805 \\
\hline 2001 & 1 & 159 & -1.22179 & -1.12847 & 0.07533 & 0.06560 & -1.32155 \\
2001 & 2 & 151 & -1.65500 & -1.31194 & 0.08179 & 0.07553 & -1.37617 \\
\hline
\end{tabular}

Table 8: Commercial paper spread regression results

\begin{tabular}{cccccc}
\hline & & \multicolumn{2}{c}{$\log \left(\frac{\mathrm{CA}}{\mathrm{CL}}\right)$} & \multicolumn{2}{c}{$\log (\mathrm{EDF})$} \\
& & Coefficient & Standard & Coefficient & Standard \\
Year & Quarter & Estimate & Error & Estimate & Error \\
\hline 1998 & 1 & -0.39615 & 0.12800 & 0.22868 & 0.06370 \\
1998 & 2 & -0.28415 & 0.11568 & 0.20095 & 0.05176 \\
1998 & 3 & -0.40917 & 0.14922 & 0.16635 & 0.04605 \\
1998 & 4 & -0.32070 & 0.13124 & 0.17165 & 0.04442 \\
\hline 1999 & 1 & -0.16905 & 0.10904 & 0.22879 & 0.03624 \\
1999 & 2 & -0.23405 & 0.08630 & 0.22607 & 0.03184 \\
1999 & 3 & -0.18159 & 0.09350 & 0.21977 & 0.03171 \\
1999 & 4 & -0.60400 & 0.19702 & 0.19707 & 0.06736 \\
\hline 2000 & 1 & -0.26459 & 0.11546 & 0.38713 & 0.04076 \\
2000 & 2 & -0.20033 & 0.06975 & 0.21741 & 0.02539
\end{tabular}

continued next page.... 
Table 8: Commercial paper spread regression results, cont.

\begin{tabular}{cccccc}
\hline & & \multicolumn{2}{c}{$\log \left(\frac{\mathrm{CA}}{\mathrm{CL}}\right)$} & \multicolumn{2}{c}{$\log (\mathrm{EDF})$} \\
& & Coefficient & Standard & Coefficient & Standard \\
Year & Quarter & Estimate & Error & Estimate & Error \\
\hline 2000 & 3 & -0.19861 & 0.09524 & 0.26181 & 0.03352 \\
2000 & 4 & -0.26947 & 0.19237 & 0.42699 & 0.05961 \\
\hline 2001 & 1 & -0.32432 & 0.14633 & 0.42530 & 0.04730 \\
2001 & 2 & -0.31607 & 0.12242 & 0.32651 & 0.04797 \\
\hline
\end{tabular}

Table 9: Commercial paper spread regression results

\begin{tabular}{cccccc}
\hline & & \multicolumn{2}{c}{ CA-CL } & \multicolumn{2}{c}{$\log (\mathrm{EDF})$} \\
& & Coefficient & Standard & Coefficient & Standard \\
Year & Quarter & Estimate & Error & Estimate & Error \\
\hline 1998 & 1 & -0.30779 & 0.11182 & 0.22511 & 0.06439 \\
1998 & 2 & -0.20934 & 0.08855 & 0.20555 & 0.05181 \\
1998 & 3 & -0.33480 & 0.10715 & 0.17946 & 0.04641 \\
1998 & 4 & -0.26230 & 0.10801 & 0.17253 & 0.04450 \\
\hline 1999 & 1 & -0.12039 & 0.08350 & 0.22964 & 0.03638 \\
1999 & 2 & -0.20525 & 0.07153 & 0.22826 & 0.03180 \\
1999 & 3 & -0.11771 & 0.07883 & 0.21622 & 0.03176 \\
1999 & 4 & -0.34675 & 0.16057 & 0.19481 & 0.06892 \\
\hline 2000 & 1 & -0.17503 & 0.09358 & 0.38701 & 0.04114 \\
2000 & 2 & -0.12851 & 0.05565 & 0.21865 & 0.02574 \\
2000 & 3 & -0.13909 & 0.08596 & 0.26751 & 0.03433 \\
2000 & 4 & -0.18940 & 0.16180 & 0.43283 & 0.06047 \\
\hline 2001 & 1 & -0.26781 & 0.13523 & 0.43515 & 0.04808 \\
2001 & 2 & -0.30626 & 0.12645 & 0.33673 & 0.04857 \\
\hline
\end{tabular}

Table 10: Commercial paper spread regression results

\begin{tabular}{lccccc}
\hline & & \multicolumn{2}{c}{$\log \left(\frac{\mathrm{CA}}{\mathrm{TA}}\right)$} & \multicolumn{2}{c}{$\log (\mathrm{EDF})$} \\
& & Coefficient & Standard & Coefficient & Standard \\
Year & Quarter & Estimate & Error & Estimate & Error \\
\hline 1998 & 1 & -0.35770 & 0.07716 & 0.28914 & 0.06144 \\
1998 & 2 & -0.31660 & 0.06864 & 0.23551 & 0.04928 \\
1998 & 3 & -0.33056 & 0.08504 & 0.17599 & 0.04482 \\
1998 & 4 & -0.32983 & 0.08522 & 0.18595 & 0.04330 \\
\hline 1999 & 1 & -0.14122 & 0.07287 & 0.23037 & 0.03607 \\
1999 & 2 & -0.20983 & 0.05646 & 0.22299 & 0.03119 \\
\multicolumn{2}{l}{ continued next page.... } & & &
\end{tabular}


Table 10: Commercial paper spread regression results, cont.

\begin{tabular}{cccccc}
\hline & & \multicolumn{2}{c}{$\log \left(\frac{\mathrm{CA}}{\mathrm{TA}}\right)$} & \multicolumn{2}{c}{$\log (\mathrm{EDF})$} \\
& & Coefficient & Standard & Coefficient & Standard \\
Year & Quarter & Estimate & Error & Estimate & Error \\
\hline 1999 & 3 & -0.16540 & 0.06032 & 0.21158 & 0.03088 \\
1999 & 4 & -0.45903 & 0.12850 & 0.19718 & 0.06655 \\
\hline 2000 & 1 & -0.22938 & 0.07760 & 0.38539 & 0.04015 \\
2000 & 2 & -0.19743 & 0.04763 & 0.21890 & 0.02473 \\
2000 & 3 & -0.25012 & 0.06216 & 0.27706 & 0.03279 \\
2000 & 4 & -0.39591 & 0.12939 & 0.45055 & 0.05904 \\
\hline 2001 & 1 & -0.34209 & 0.09492 & 0.44517 & 0.04665 \\
2001 & 2 & -0.26273 & 0.07930 & 0.33773 & 0.04757 \\
\hline
\end{tabular}

Table 11: Means of variables for bond spread regressions

\begin{tabular}{cccccccc}
\hline & & \multicolumn{7}{c}{ Average } & & & \\
Year & Quarter & $\mathrm{N}$ & $\log$ Spread & $\log (\mathrm{EDF})$ & $\log \left(\frac{\mathrm{CA}}{\mathrm{CL}}\right)$ & $\frac{\mathrm{CA}-\mathrm{CL}}{\sigma_{A}}$ & $\log \left(\frac{\mathrm{CA}}{\mathrm{TA}}\right)$ \\
\hline 1998 & 1 & 146 & -0.45593 & -2.73041 & 0.20325 & 0.18484 & -1.36953 \\
1998 & 2 & 156 & -0.41361 & -2.49938 & 0.18507 & 0.18900 & -1.35924 \\
1998 & 3 & 163 & 0.17767 & -1.93893 & 0.14606 & 0.17143 & -1.34864 \\
1998 & 4 & 168 & 0.13233 & -1.91741 & 0.14203 & 0.13767 & -1.39613 \\
\hline 1999 & 1 & 162 & -0.01641 & -1.73102 & 0.16047 & 0.16975 & -1.42104 \\
1999 & 2 & 180 & 0.11633 & -1.86951 & 0.17680 & 0.14729 & -1.41245 \\
1999 & 3 & 153 & 0.22198 & -1.52290 & 0.23849 & 0.19999 & -1.38111 \\
1999 & 4 & 160 & 0.21020 & -1.35211 & 0.18202 & 0.13497 & -1.44228 \\
\hline 2000 & 1 & 164 & 0.31690 & -1.04954 & 0.15239 & 0.08154 & -1.48833 \\
2000 & 2 & 171 & 0.62067 & -0.82194 & 0.14259 & 0.08297 & -1.45321 \\
2000 & 3 & 172 & 0.62719 & -0.77719 & 0.11761 & 0.07563 & -1.43009 \\
2000 & 4 & 174 & 0.75860 & -0.93977 & 0.11276 & 0.07058 & -1.43109 \\
\hline 2001 & 1 & 174 & 0.65939 & -0.84927 & 0.11106 & 0.08951 & -1.45690 \\
2001 & 2 & 182 & 0.54929 & -1.01454 & 0.10489 & 0.07287 & -1.49512 \\
\hline
\end{tabular}

Table 12: Bond spread regression results

\begin{tabular}{lccccc}
\hline & \multicolumn{2}{c}{$\log \left(\frac{\mathrm{CA}}{\mathrm{CL}}\right)$} & \multicolumn{2}{c}{$\log (\mathrm{EDF})$} \\
& & Coefficient & Standard & Coefficient & Standard \\
Year & Quarter & Estimate & Error & Estimate & Error \\
\hline 1998 & 1 & 0.04302 & 0.10511 & 0.16553 & 0.04228 \\
1998 & 2 & 0.00213 & 0.06603 & 0.14684 & 0.02621 \\
1998 & 3 & 0.02758 & 0.05294 & 0.14407 & 0.01807 \\
\multicolumn{2}{l}{$\begin{array}{l}\text { continued next page.... } \\
l\end{array}$}
\end{tabular}


Table 12: Bond spread regression results, cont.

\begin{tabular}{cccccc}
\hline & & \multicolumn{2}{c}{$\log \left(\frac{\text { CA }}{\text { CL }}\right)$} & \multicolumn{2}{c}{$\log (\mathrm{EDF})$} \\
Year & Quarter & Estimate & $\begin{array}{c}\text { Error } \\
\text { Esticiendard }\end{array}$ & $\begin{array}{c}\text { Coefficient } \\
\text { Estimate }\end{array}$ & $\begin{array}{c}\text { Standard } \\
\text { Error }\end{array}$ \\
\hline 1998 & 4 & 0.01379 & 0.06595 & 0.19590 & 0.02383 \\
\hline 1999 & 1 & 0.01442 & 0.07123 & 0.25376 & 0.02505 \\
1999 & 2 & 0.05761 & 0.04945 & 0.17331 & 0.01850 \\
1999 & 3 & 0.05483 & 0.05208 & 0.18008 & 0.01902 \\
1999 & 4 & 0.08630 & 0.04986 & 0.21552 & 0.01833 \\
\hline 2000 & 1 & 0.08688 & 0.03982 & 0.19808 & 0.01687 \\
2000 & 2 & 0.06802 & 0.04140 & 0.18303 & 0.01796 \\
2000 & 3 & 0.07951 & 0.04482 & 0.17376 & 0.01826 \\
2000 & 4 & 0.17364 & 0.05567 & 0.24610 & 0.02323 \\
\hline 2001 & 1 & 0.18507 & 0.05828 & 0.28512 & 0.02774 \\
2001 & 2 & 0.10937 & 0.05657 & 0.23277 & 0.02885 \\
\hline
\end{tabular}

Table 13: Bond spread regression results

\begin{tabular}{cccccc}
\hline & \multicolumn{2}{c}{$\frac{\text { CA-CL }}{\sigma}$} & \multicolumn{2}{c}{$\log (\mathrm{EDF})$} \\
& & Coefficient & Standard & Coefficient & Standard \\
Year & Quarter & Estimate & Error & Estimate & Error \\
\hline 1998 & 1 & 0.03456 & 0.09712 & 0.16626 & 0.04213 \\
1998 & 2 & -0.00293 & 0.06102 & 0.14726 & 0.02629 \\
1998 & 3 & 0.01000 & 0.04302 & 0.14532 & 0.01815 \\
1998 & 4 & -0.04648 & 0.06293 & 0.20152 & 0.02395 \\
\hline 1999 & 1 & -0.03520 & 0.05784 & 0.25945 & 0.02531 \\
1999 & 2 & 0.01059 & 0.04802 & 0.17749 & 0.01874 \\
1999 & 3 & -0.02254 & 0.04870 & 0.18769 & 0.01911 \\
1999 & 4 & 0.04382 & 0.04673 & 0.21615 & 0.01856 \\
\hline 2000 & 1 & 0.06344 & 0.03926 & 0.19638 & 0.01708 \\
2000 & 2 & 0.05314 & 0.03952 & 0.17964 & 0.01813 \\
2000 & 3 & 0.11291 & 0.04062 & 0.16601 & 0.01821 \\
2000 & 4 & 0.20301 & 0.05233 & 0.23611 & 0.02312 \\
\hline 2001 & 1 & 0.14798 & 0.05256 & 0.28106 & 0.02787 \\
2001 & 2 & 0.05750 & 0.05113 & 0.23150 & 0.02904 \\
\hline
\end{tabular}


Table 14: Bond spread regression results

\begin{tabular}{cccccc}
\hline & & \multicolumn{2}{c}{$\log \left(\frac{\mathrm{CA}}{\text { TA }}\right)$} & \multicolumn{2}{c}{$\log (\mathrm{EDF})$} \\
& & Coefficient & Standard & Coefficient & Standard \\
Year & Quarter & Estimate & Error & Estimate & Error \\
\hline 1998 & 1 & -0.03678 & 0.06321 & 0.17345 & 0.04261 \\
1998 & 2 & -0.08739 & 0.03936 & 0.15883 & 0.02588 \\
1998 & 3 & -0.04348 & 0.03174 & 0.15097 & 0.01788 \\
1998 & 4 & -0.04598 & 0.04274 & 0.20080 & 0.02339 \\
\hline 1999 & 1 & 0.01666 & 0.04322 & 0.25421 & 0.02435 \\
1999 & 2 & -0.00249 & 0.03282 & 0.17877 & 0.01806 \\
1999 & 3 & -0.04806 & 0.03464 & 0.18595 & 0.01832 \\
1999 & 4 & -0.03452 & 0.03486 & 0.21795 & 0.01837 \\
\hline 2000 & 1 & -0.03173 & 0.02809 & 0.19900 & 0.01704 \\
2000 & 2 & -0.02248 & 0.02906 & 0.18316 & 0.01809 \\
2000 & 3 & 0.00137 & 0.03045 & 0.17319 & 0.01848 \\
2000 & 4 & 0.04914 & 0.03999 & 0.24785 & 0.02377 \\
\hline 2001 & 1 & 0.02406 & 0.04278 & 0.27942 & 0.02862 \\
2001 & 2 & 0.00528 & 0.04424 & 0.23151 & 0.02929 \\
\hline
\end{tabular}




\section{References}

Altman, E. I. and Kishore, V. M.: 1996, Almost everything you wanted to know about recoveries on defaulted bonds, Financial Analysts Journal pp. 57-64.

Andersen, T. G., Bollerslev, T., Diebold, F. X. and Ebens, H.: 2001, The distribution of realized stock return volatility, Journal of Financial Economics 61, 43-76.

Andersen, T. G., Bollerslev, T., Diebold, F. X. and Labys, P.: 2002, Modeling and forecasting realized volatility. Manuscript, Departments of Economics, Northwestern University, Duke University and University of Pennsylvania.

Black, F. and Cox, J. C.: 1976, Valuing corporate securities: Some effects of bond indenture provisions, Journal of Finance 31(2), 351-367.

Collin-Dufresne, P. and Goldstein, R. S.: 2001, Do credit spreads reflect stationary leverage ratios?, Journal of Finance pp. 1929-1957.

Duffie, D. and Singleton, K. J.: 1999, Modeling term structures of defaultable bonds, The Review of Financial Studies 12(4), 687-720.

Eom, Y. H., Helwege, J. and zhi Huang, J.: 2002, Structural models of corporate bond pricing: An empirical analysis. Working paper.

Geske, R.: 1977, The valuation of corporate liabilities as compound options, Journal of Financial and Quantitative Analysis 12, 541-552.

He, J., Hu, W. and Lang, L.: 2000, Credit spread curves and credit ratings. Working paper.

Helwege, J. and Turner, C.: 1999, The slope of the credit yield curve for speculative-grade issuers, Journal of Finance pp. 1869-1885.

Jones, E. P., Mason, S. P. and Rosenfeld, E.: 1984, Contingent claims analysis of corporate capital structures: An empirical investigation, Journal of Finance 39(3), 611-625.

Leland, H. E.: 1994, Corporate debt value, bond covenants, and optimal capital structure, Journal of Finance 49(4), 1213-1252.

Leland, H. E. and Toft, K. B.: 1996, Optimal capital structure, endogenous bankruptcy, and the term structure of credit spreads, Journal of Finance 3(51), 987-1019.

Longstaff, F. A.: 2000, The term structure of very short-term rates: New evidence for the expectations hypothesis, Journal of Financial Economics 58, 397-415.

Longstaff, F. A. and Schwartz, E. S.: 1995, A simple approach to valuing risk fixed and floating-rate debt, Journal of Finance 50, 789-819.

Lyden, S. and Saraniti, D.: 2000, An empirical examination of the classical theory of corporate security valuation. Barclays Global Investors. 
Merton, R. C.: 1974, On the pricing of corporate debt: The risk structure of interest rates, Journal of Finance 29(2), 449-470.

Merton, R. C.: 1976, Option pricing when underlying stock returns are discontinuous, Journal of Financial Economics 3, 125-144.

Ogden, J. P.: 1987, Determinants of the ratings changes and yields on corporate bonds: Tests of the contingent claims model, The Journal of Financial Research 10(4), 329-339.

Sarig, O. and Warga, A.: 1989, Some empirical estimates of the risk structure of interest rates, Journal of Finance 44(5), 1351-1360.

Stigum, M. L.: 1986, After the Trade: Dealer and Clearing-Bank Operations in Government and Money Market Securities, The McGraw-Hill Companies.

Stigum, M. L.: 1990, The Money Market, Dow Jones-Irwin.

Warga, A.: 1991, Corporate bond price discrepancies in the dealer and exchange markets, Journal of Fixed Income 1, 7-16.

Warga, A. and Welch, I.: 1993, Bondholder losses in leveraged buyouts, The Review of Financial Studies 4, 959-982. 